\title{
ATRC Neutron Detector Testing Quick Look Report
}

\author{
T. C. Unruh \\ B. M. Chase \\ J. L. Rempe
}

August 2013

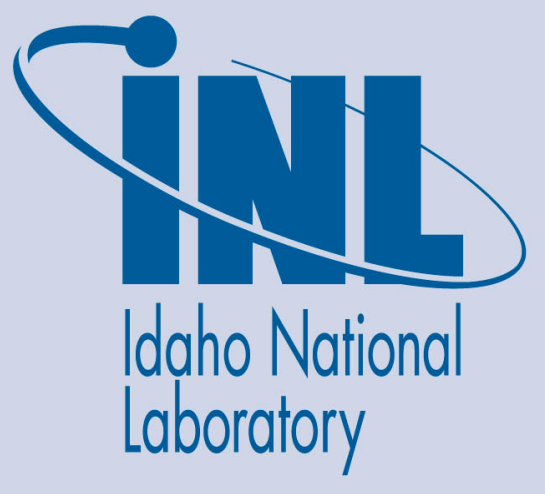

The INL is a U.S. Department of Energy National Laboratory operated by Battelle Energy Alliance 
INL/EXT-13-29896

\section{ATRC Neutron Detector Testing Quick Look Report}

T. C. Unruh

B.M. Chase

J. L. Rempe

August 2013

\section{Idaho National Laboratory \\ Idaho Falls, Idaho 83415}

http://www.inl.gov

Prepared for the

U.S. Department of Energy

Office of Nuclear Energy

Under DOE Idaho Operations Office

Contract DE-AC07-05ID14517 


\section{DISCLAIMER}

This information was prepared as an account of work sponsored by an agency of the U.S. Government. Neither the U.S. Government nor any agency thereof, nor any of their employees, makes any warranty, express or implied, or assumes any legal liability or responsibility for the accuracy, completeness, or usefulness of any information, apparatus, product, or process disclosed, or represents that its use would not infringe privately owned rights. References herein to any specific commercial product, process, or service by trade name, trademark, manufacturer, or otherwise, does not necessarily constitute or imply its endorsement, recommendation, or favoring by the U.S. Government or any agency thereof. The views and opinions of authors expressed herein do not necessarily state or reflect those of the U.S. Government or any agency thereof. 


\section{CONTENTS}

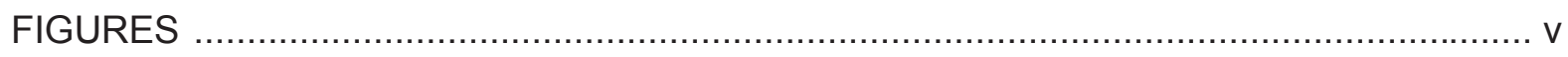

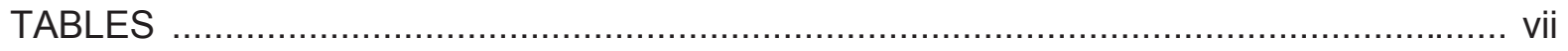

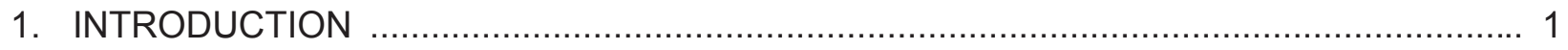

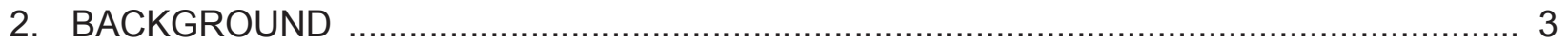

2.1. Previous Work and Supporting Documentation ............................................ 4

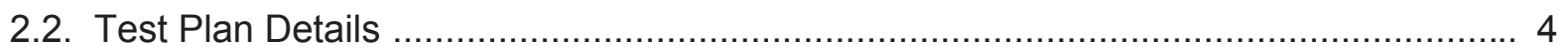

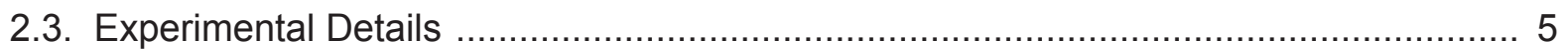

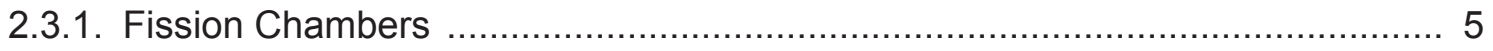

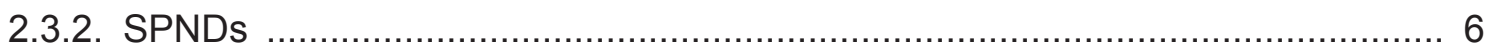

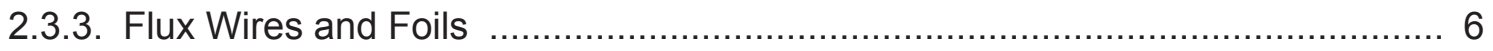

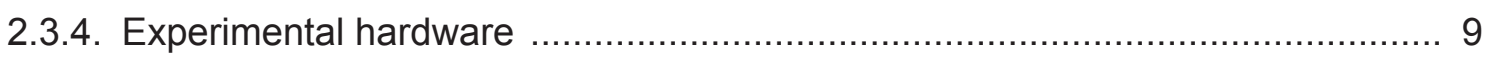

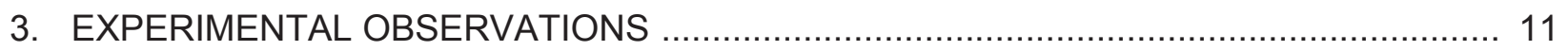

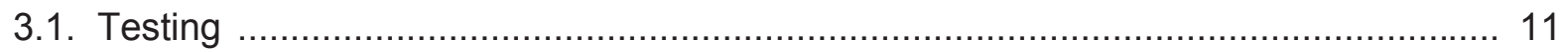

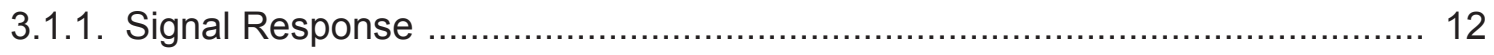

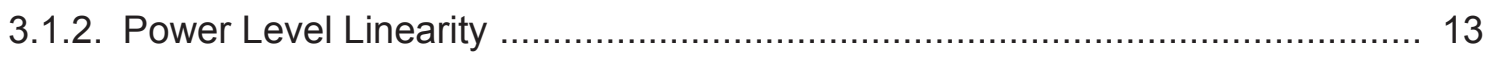

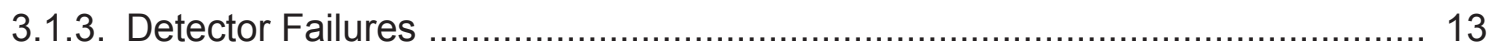

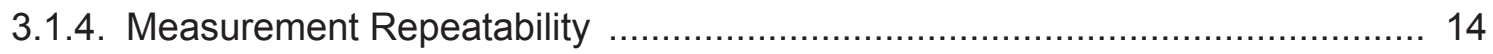

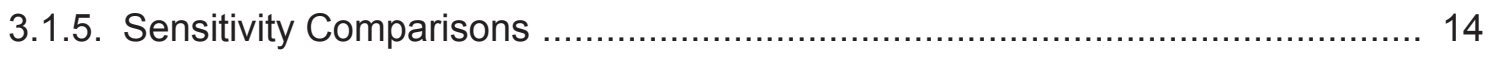

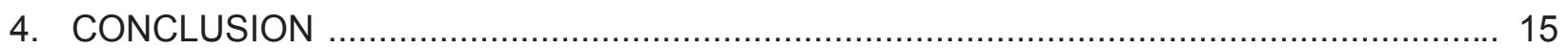

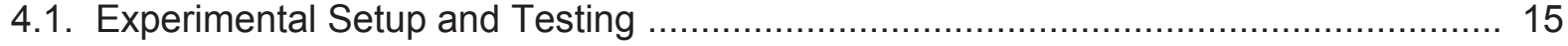

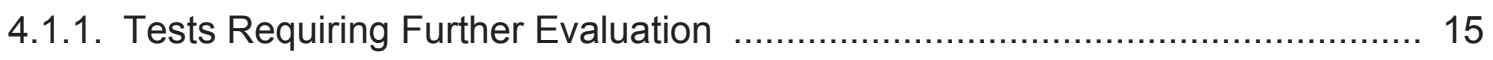

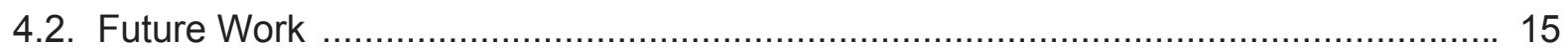

4.2.1. Back-to-Back (BTB) Fission chamber .............................................. 15

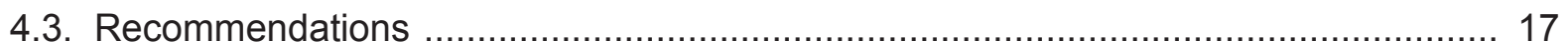

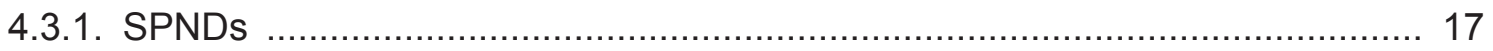

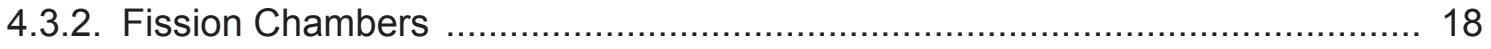

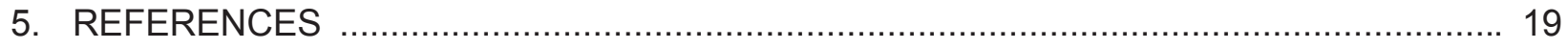

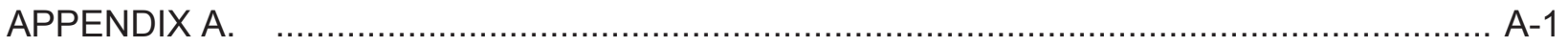


INL/EXT-13-29896 


\section{FIGURES}

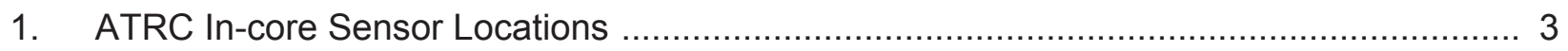

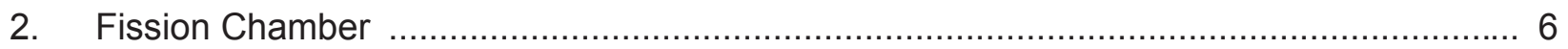

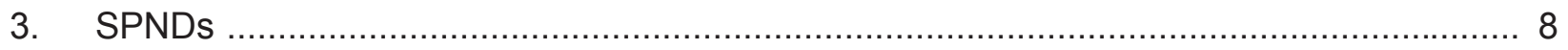

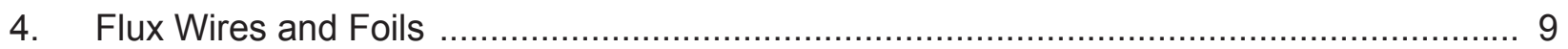

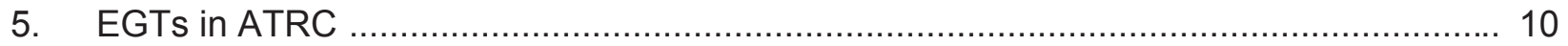

6. Comparison of Power Measurements Obtained from Rhodium SPNDs and a Fission Chamber from Activity III, Test 8, Experimental Configuration C ....................... 11

7. Axial Flux Profile from Rhodium SPNDs and a Fission Chamber from Activity

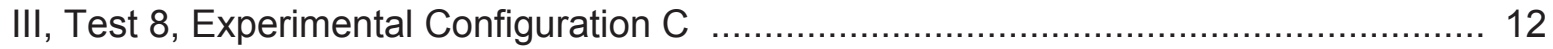

8. Axial Flux Profile from Rhodium SPNDs and a Fission Chamber, Before and After a Reactor Restart with the EGTs Located at Core Centerline from Activity III, Test 2, Experimental Configuration A 13

9. Fabricated Back-to-Back Fission Chamber Fixtures …....................................... 16

10. Back-to-Back Fission Chamber Hardware Assembly ............................................. 17 
INL/EXT-13-29896 


\section{TABLES}

1. Summary Description of the Planned Experimental Activities................................... 3

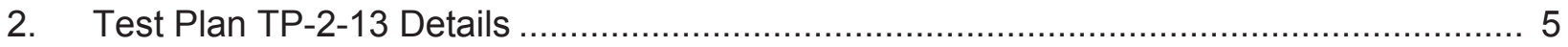

3. In-core Neutron Detector Characteristics Under Evaluation .......................................... 7

4. Standard In-core Neutron Detector Characteristics ............................................. 9

A-1. Activity III, Test 2, Experimental Configuration A, Axial Measurements...................... A-1

A-2. Activity III, Test 2, Experimental Configuration A, Power Linearity Measurements.......... A-2

A-3. Activity IV-A, Test 3, Experimental Configuration A, Power Split Measurements ............ A-2

A-4. Activity IV-A, Test 5, Experimental Configuration B, NW Balanced, Power Linearity Measurements

A-5. Activity IV-A, Test 5, Experimental Configuration B, NW Unbalanced +4, Power Linearity Measurements

A-6. Activity IV-A, Test 5, Experimental Configuration B, NW Unbalanced -4, Power Linearity Measurements

A-7. Activity IV-A, Test 6, Experimental Configuration B, Balanced, Axial Measurements

A-8. Activity IV-A, Test 6, Experimental Configuration B, NW Unbalanced +4, Axial Measurements

A-9. Activity IV-A, Test 6, Experimental Configuration B, NW Unbalanced -4, Axial Measurements A-7

A-10.Activity III, Test 8, Experimental Configuration C, Axial Measurements A-8

A-11.Activity III, Test 8, Experimental Configuration C, Power Linearity Measurements A-9 A-12.Activity IV, Test 9, Experimental Configuration C, Power Split Measurements A-9 
INL/EXT-13-29896 


\section{INTRODUCTION}

As part of the Advanced Test Reactor (ATR) National Scientific User Facility (NSUF) program, a joint Idaho State University (ISU) / French Alternative Energies and Atomic Energy Commission (CEA) / Idaho National Laboratory (INL) project was initiated in FY-10 to investigate the feasibility of using neutron sensors to provide online measurements of the neutron flux and fission reaction rate in the ATR Critical Facility (ATRC). A second objective was to provide initial neutron spectrum and flux distribution information for physics modeling and code validation using neutron activation based techniques in ATRC as well as ATR during depressurized operations. Detailed activation spectrometry measurements were made in the flux traps and in selected fuel elements, along with standard fission rate distribution measurements at selected core locations. These measurements provide additional calibration data for the real-time sensors of interest as well as provide benchmark neutronics data that will be useful for the ATR Life Extension Program (LEP) Computational Methods and V\&V Upgrade project. As part of this effort, techniques developed by Prof. George Imel will be applied by Idaho State University (ISU) for assessing the performance of various flux detectors to develop detailed procedures for initial and follow-on calibrations of these sensors. In addition to comparing data obtained from each type of detector, calculations will be performed to assess the performance of and reduce uncertainties in flux detection sensors and compare data obtained from these sensors with existing integral methods employed at the ATRC.

The neutron detectors required for this project were provided to team participants at no cost. Activation detectors (foils and wires) from an existing, well-characterized INL inventory were employed. Furthermore, as part of an on-going ATR NSUF international cooperation, the CEA sent INL three miniature fission chambers (one for detecting fast flux and two for detecting thermal flux) with associated electronics for assessment. In addition, Prof. Imel, ISU, has access to an inventory of Self-Powered Neutron Detectors (SPNDs) with a range of response times as well as Back-to-Back (BTB) fission chambers from prior research he conducted at the Transient REActor Test Facility (TREAT) facility and Neutron RADiography (NRAD) reactors. Finally, SPNDs from the National Atomic Energy Commission of Argentina (CNEA) were provided in connection with the INL effort to upgrade ATR computational methods and V\&V protocols that are underway as part of the ATR LEP.

Work during fiscal year 2010 (FY10) focussed on design and construction of Experiment Guide Tubes (EGTs) for positioning the flux detectors in the ATRC N-16 locations as well as obtaining ATRC staff concurrence for the detector evaluations. Initial evaluations with CEA researchers were also started in FY10 but were cut short due to reactor reliability issues. Reactor availability issues caused experimental work to be delayed during FY11/12. In FY13, work resumed; and evaluations were completed.

The objective of this "Quick Look" report is to summarize experimental activities performed from April 4, 2013 through May 16, 2013. This report documents the data and observations obtained while completing these activities, allowing ISU and other interested organizations, such as CEA, the opportunity to evaluate the performance of detectors included in this program. Previous work and documentation related to testing are discussed in Section 2. The observations for the most recent testing campaign are described in Section 3. Conclusions, recommendations, and proposed future work are summarized in Section 4. References are listed in Section 5. 


\section{BACKGROUND}

Understanding neutron flux in a nuclear reactor is critical for safe operation of the reactor as well as for evaluating experiments in MTRs. Recently, it has become increasingly clear that further research into real-time flux sensors are needed to evaluate operating conditions as well as fuels and materials tests in ATR. Several activities were planned to research real-time detectors. As documented in Reference 1 and 2 (see Table 1), four specific activities were envisioned to be completed in this project. Each activity has 3 experimental configurations associated with the detector evaluations (see Figure 1). All of these activities were completed except Activity 4B. It is anticipated that Activity 4B will be completed at the end of FY-13.

Table 1. Summary Description of the Planned Experimental Activities.

\begin{tabular}{|c|l|}
\hline Activity & \multicolumn{1}{|c|}{ Description } \\
\hline I & $\begin{array}{l}\text { A. Install and perform mechanical tests of Experiment Guide Tube (EGT) positioning devices for the N-16 } \\
\text { positions with the ATRC in a shutdown configuration. } \\
\text { B. Experimentally evaluate potential radiation hazards to personnel due to neutron streaming to the surface of the } \\
\text { ATRC water tank up the EGT assemblies. This is done via a series of low-power ATRC runs with the guide tube } \\
\text { assemblies and dry tubes installed, but without instrumentation in place. }\end{array}$ \\
\hline II & $\begin{array}{l}\text { A. Perform NW Flux Trap activation foil and wire irradiations for each of three critical shim positions at } 600 \\
\text { watts, beginning with the balanced configuration. } \\
\text { B. Perform core flux wire irradiation with U/AL and Cu/Au wires for the balanced critical shim position at } 600 \\
\text { watts. }\end{array}$ \\
\hline III & $\begin{array}{l}\text { Test SPND detectors in the ATRC N-16 guide tubes in the positions of interest shown in Figure 1, with three } \\
\text { different critical configurations of the outer shim cylinders. For each configuration, ascend to 600 watts with at } \\
\text { least four intermediate power levels beginning at approximately 1 milliwatt. With each configuration at the } \\
\text { maximum power, measure the axial flux profiles in the 6 N-16 locations shown in Figure 1. }\end{array}$ \\
\hline IV & $\begin{array}{l}\text { A. Test SPND and fission chamber detectors in the ATRC N-16 guide tubes in the positions of interest shown in } \\
\text { Figure 1, with three different critical configurations of the outer shim cylinders. For each configuration, ascend to } \\
\text { 600 watts with at least four intermediate power levels beginning at approximately 1 milliwatt. With each } \\
\text { configuration at the maximum power, measure the axial flux profiles in the locations shown in Figure 1. } \\
\text { B. Test the BTB fission chambers in the NW IPT. For this test, there may be multiple runs, to accommodate tests } \\
\text { with a co-located fast fission chamber, a collocated thermal fission chamber, and with co-located fast and thermal } \\
\text { fission chambers. During each run, SPNDs will be positioned in the N-16 positions to monitor power. }\end{array}$ \\
\hline
\end{tabular}

\begin{tabular}{|c|c|c|c|}
\hline & \multicolumn{3}{|c|}{ Experimental Configurations } \\
\hline & & & C \\
\hline 0 & $\begin{array}{c}\text { U-235 FC } \\
\# 2253\end{array}$ & $\underset{\# 4}{\mathrm{U}-238 \mathrm{FC}}$ & $\begin{array}{c}\text { Rh SPND } \\
\text { \#DN3 }\end{array}$ \\
\hline & $\begin{array}{c}\text { Hf SPND } \\
\# 658\end{array}$ & $\begin{array}{l}\text { Rh SPND } \\
\text { \#DN1 }\end{array}$ & $\begin{array}{c}\text { Rh SPND } \\
\# \text { DN } 1\end{array}$ \\
\hline & $\begin{array}{c}\text { U-235 FC } \\
\# 2252\end{array}$ & $\begin{array}{c}\text { U-235 FC } \\
\# 2253\end{array}$ & $\begin{array}{c}\text { U-235 FC } \\
\# 2253\end{array}$ \\
\hline & $\underset{\# 4}{\mathrm{U}-238 \mathrm{FC}}$ & $\begin{array}{c}\text { Hf SPND } \\
\# 657\end{array}$ & $\begin{array}{l}\text { Rh SPND } \\
\text { \#DN4 }\end{array}$ \\
\hline & $\begin{array}{c}\text { Gd SPND } \\
\# 663\end{array}$ & $\begin{array}{c}\text { U-235 FC } \\
\# 2252\end{array}$ & $\begin{array}{l}\text { Rh SPND } \\
\text { \#DN5 }\end{array}$ \\
\hline & $\begin{array}{c}\text { Hf SPND } \\
\# 657\end{array}$ & $\begin{array}{c}\text { Hf SPND } \\
\# 658\end{array}$ & $\begin{array}{c}\text { Rh SPND } \\
\text { \#DN2 }\end{array}$ \\
\hline
\end{tabular}

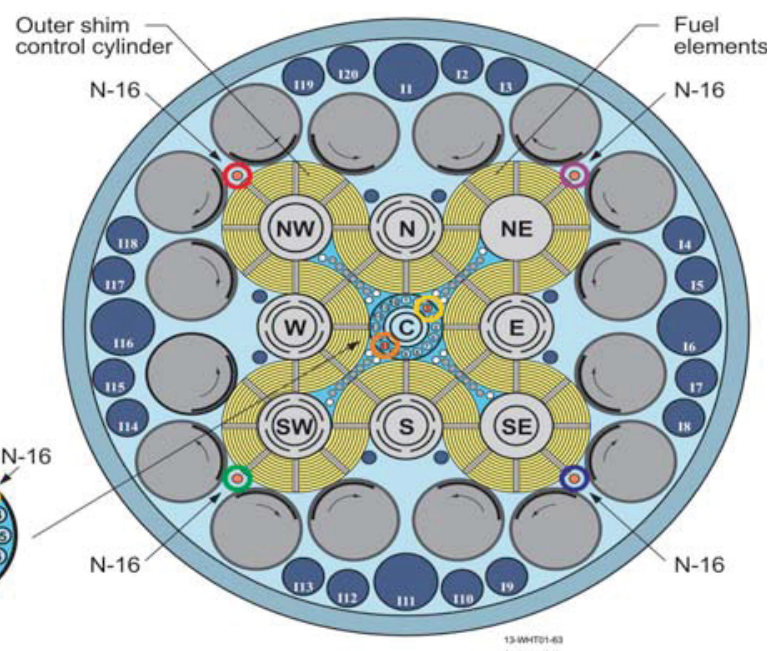

Figure 1. ATRC In-core Sensor Locations 


\subsection{Previous Work and Supporting Documentation}

Initial work performed in FY-10 included Activity 1A/1B. Activity 3B was started, but not completed due to reactor reliability issues. Activity $1 \mathrm{~A}$ was completed in TP-2-10, "N-16 Experiment Guide Tube Mock-up fitment in ATRC." Activity 1B was completed, and activity 3B was started in TP-4-10, "N-16 Experiment Guide Tube Testing."

Activity 2A/2B was performed under test plan TP-3-10, "Flux Runs for Activation Foil Measurements" 6 and test plan TP-3-12, "Activation Foil Measurements - Irradiation 5"7 with results detailed in INL/EXT-10-19940 and INL/EXT-11-23348, "Advanced Test Reactor Core Modeling Update Project Annual Report for Fiscal Year 2010"8 and "Advanced Test Reactor Core Modeling Update Project Annual Report for Fiscal Year 2011."9

In addition, previous work of interest for validation purposes includes the flux run 12-8 for core loading 12-13 performed in TP-4-12, "SE-192 Reactivity and Axial Flux Measurement"10 with results detailed in ECAR-2089, "RML Data Package Flux Run 12-8 TP-4-12"11. This test plan was performed for the Bettis SE-192 experiment and was the last core configuration prior to starting TP-2-13 that was used for these in-core sensor evaluations. Hence, it is the most applicable flux measurements with the only minor exception being that the N-16 mock-ups are removed and the EGTs/dry tubes/detectors are in their place. However, it should be noted that the core loadings don't match exactly due to a typo in the TP-4-12 test plan for the H-position irradiation facilities. The H-position irradiation loadings listed in TP-2-13 are correct, and the same for TP-4-12.

\subsection{Test Plan Details}

An ATRC test plan governs the operation of ATRC and must be written to meet the experimental objectives. The test plan describes the ATRC Facility core changes and operations to be performed to test in-core neutron detectors in 6 Experiment Guide Tube (EGT) assemblies in the 4 inner lobe and 2 Center Flux Trap (CFT) N-16 locations. As outlined in Table 2, the first test will insert the in-core neutron detectors to test signal response at various power levels up to 600 watts and test the vertical movement of the EGT/dry tube/detector assemblies at 600 watts. The second test will evaluate the in-core detectors at various power levels up to 600 watts with the in-core detectors at core mid-plane and then measure the axial flux profile of the core at 600 watts. The third test will place the in-core detectors at core mid-plane and measure the power split for 3 outer shim configurations, balanced, un-balanced toward NW, and un-balanced away from NW. The fourth, fifth and sixth tests will remove the installed in-core neutron detectors and insert different in-core neutron detectors that are capable of measuring fast and thermal neutron fluxes. The fourth test will repeat the tests performed in tests 1,2, and 3 as well as perform a measurement of the ratio between the response for the thermal in-core detector and the fast in-core detector for a balanced Outer Shim Control Cylinder (OSCC) configuration. The fifth test will repeat the tests performed in tests 2 and 3 as well as perform a measurement of the ratio between the response for the thermal in-core detector and the fast in-core detector for an unbalanced core toward the northwest lobe OSCC configuration. The sixth test will repeat the tests performed in tests 2 and 3 as well as perform a measurement of the ratio between the response for the thermal in-core detector and the fast in-core detector for an unbalanced core away from the northwest lobe OSCC configuration. The seventh, eighth and ninth tests will repeat the tests performed in tests 1, 2, and 3 with different in-core detectors. Test objectives from the test plan are detailed 
in Table 2.

Table 2. Test Plan TP-2-13 Details

\begin{tabular}{|c|c|c|c|}
\hline Activity & $\begin{array}{l}\text { Experimental } \\
\text { Configuration }\end{array}$ & Test & Description/Objective \\
\hline III & A & 1) Detector checkout & $\begin{array}{l}\text { Verify detector response to neutrons and set } \\
\text { fission chamber voltages }\end{array}$ \\
\hline III & A & 2) Power linearity tests & Verify detector response to power levels \\
\hline III & A & $\begin{array}{l}\text { 2) Axial flux profile } \\
\text { setup }\end{array}$ & $\begin{array}{l}\text { Measure axial flux profile to determine } \\
\text { location for maximum flux }\end{array}$ \\
\hline III & A & $\begin{array}{l}\text { 2) Axial flux profile } \\
\text { measurement }\end{array}$ & Measure axial flux profile \\
\hline IV-A & A & $\begin{array}{l}\text { 3) Reactor power split } \\
\text { measurements }\end{array}$ & $\begin{array}{l}\text { Measure detector response when OSCCs are: } \\
\text { 1) balanced, 2)with the NW OSCCs }+4 \text { from } \\
\text { balanced position, and 3) with the NW OSCCs } \\
-4 \text { from balanced position }\end{array}$ \\
\hline IV-A & B & 4) Detector checkout & Verify detector response to neutrons \\
\hline IV-A & B & 5)Power linearity tests & $\begin{array}{l}\text { Verify detector response to power levels when } \\
\text { OSCCs are: 1) balanced, 2)with the NW } \\
\text { OSCCs }+4 \text { from balanced position, and } 3 \text { ) with } \\
\text { the NW OSCCs }-4 \text { from balanced position }\end{array}$ \\
\hline IV-A & B & $\begin{array}{l}\text { 6) Axial flux profile } \\
\text { measurement with } \\
\text { power split }\end{array}$ & $\begin{array}{l}\text { Measure axial flux profile when OSCCs are: } 1 \text { ) } \\
\text { balanced, 2)with the NW OSCCs }+4 \text { from } \\
\text { balanced position, and 3) with the NW OSCCs } \\
-4 \text { from balanced position }\end{array}$ \\
\hline III & $\mathrm{C}$ & 7) Detector checkout & Verify detector response to neutrons \\
\hline III & $\mathrm{C}$ & 8) Power linearity tests & Verify detector response to power levels \\
\hline III & $\mathrm{C}$ & $\begin{array}{l}\text { 8) Axial flux profile } \\
\text { measurement }\end{array}$ & Measure axial flux profile \\
\hline IV-A & $\mathrm{C}$ & $\begin{array}{l}\text { 9) Reactor power split } \\
\text { measurements }\end{array}$ & $\begin{array}{l}\text { Measure detector response when OSCCs are: } \\
\text { 1) balanced, 2)with the NW OSCCs }+4 \text { from } \\
\text { balanced position, and 3) with the NW OSCCs } \\
-4 \text { from balanced position }\end{array}$ \\
\hline
\end{tabular}

\subsection{Experimental Details}

Several types of neutron detectors were evaluated to understand the operational characteristics needed for use in ATRC and for ATR experiments. Details related to the design, operation and evaluation of each type of sensor is discussed in the following sections.

\subsubsection{Fission Chambers}

Fission chambers, which are ion chambers with a fissionable material deposit on the inner wall, offer a method for real-time flux measurement (see Figure 2). The fission fragments provide a very large pulse from the neutron-induced reaction and can be used in either pulse or direct current mode. Normally highly-enriched ${ }^{235} \mathrm{U}$ is used for the coating, which makes them sensitive to thermal neutrons. However, other deposits can be used, such as ${ }^{238} \mathrm{U},{ }^{242} \mathrm{Pu}$, or ${ }^{232} \mathrm{Th}$, providing a higher neutron energy cutoff.

Characteristics of the miniature fission chambers included in the ATRC evaluations are listed in Table 3. Miniature fission chambers are used in pulse mode using current preamplifier electronics. Uranium coat- 

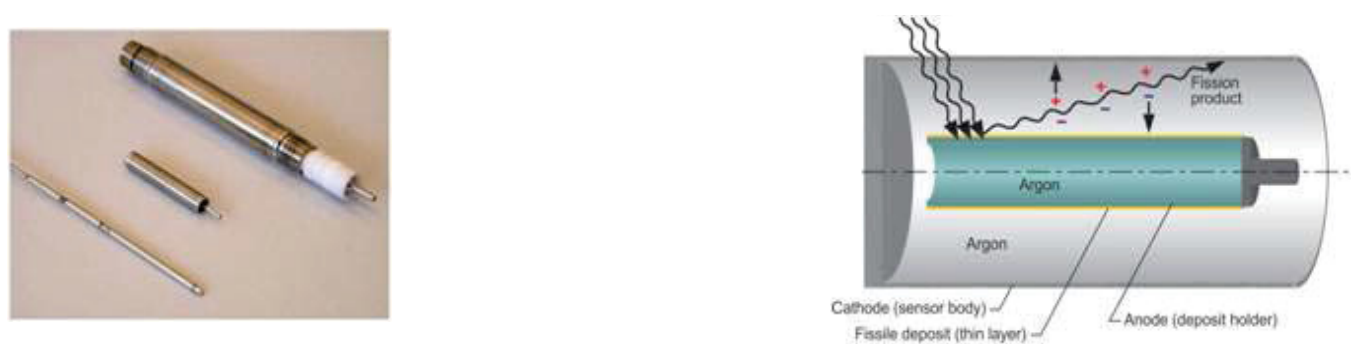

Figure 2. Fission Chamber

ing masses were chosen in order to provide a high fission rate in ATRC flux (from $10^{3}$ to $10^{5} \mathrm{cps}$ ). To protect these fission chambers and to preclude any leakage from fission chamber components into the ATRC coolant, chambers were placed in tinted Lucite tubes.

\subsubsection{SPNDs}

SPNDs have been used effectively as in-core flux monitors for decades in commercial nuclear power reactors and materials testing reactors world-wide. SPNDs rely on interactions of neutrons and atomic nuclei to produce a current which is proportional to the neutron flux.

A typical SPND consists of a coaxial cable containing an inner electrode (the emitter), which is surrounded by insulation and an outer electrode (the collector). In an "integral SPND," the lead cable and detector are mated directly to each other; the insulation of both sections are identical; and the collector of the detector section is also the outer sheath of the lead cable section (see Figure 3). Modular SPND assemblies are made from separate detector and lead cable sections. Typically, SPND characteristics of interest include size, material compatibility at high temperatures, sensitivity, response time, and burn-up rate.

Characteristics of SPNDs evaluated in this project are listed in Table 3. SPNDs were also placed in tinted Lucite tubes to prevent any unwanted leakage of component materials (if they are not leak-tight) and to reduce unwanted noise from the SPND cables being in contact with metal surfaces. SPNDs were inserted into the ATRC N-16 positions using the EGTs.

\subsubsection{Flux Wires and Foils}

While not evaluated during the time period covered in this quick look report, testing flux wires and foils provide validation data to determine the neutron flux and neutron spectrum used during evaluations. An example of the various flux wires and foils with the accompanying test hardware is shown in Figure 4. 
Table 3. In-core Neutron Detector Characteristics Under Evaluation

\begin{tabular}{|c|c|c|c|c|c|}
\hline Detector & \multicolumn{5}{|c|}{ Composition, Geometry, and Mass } \\
\hline $\begin{array}{c}\text { CEA Miniature } \\
\text { Fission } \\
\text { Chambers }\end{array}$ & Fissile Deposit & Anode/Fill Gas & $\begin{array}{c}\text { Cathode / Fill } \\
\text { Gas }\end{array}$ & Extension Cable & $\begin{array}{l}\text { Maximum Core } \\
\text { Insertion Mass }\end{array}$ \\
\hline $\begin{array}{l}\text { Miniature } \\
\text { Thermal } \\
\text { Fission } \\
\text { Chamber }\end{array}$ & $\begin{array}{l}\text { Mass } 30 \mu \mathrm{g} \\
\text { (deposit on anode) } \\
\text { U-235 } 98.5 \% \\
\text { U-234 } 0.063 \% \\
\text { U-236 } 0.038 \% \\
\text { U-238 } 1.409 \%\end{array}$ & \begin{tabular}{|l} 
Material: \\
SS304L \\
(impurities of Co \\
$0.02 \%$ ) \\
ID: $1.6 \mathrm{~mm}$ \\
OD: $2 \mathrm{~mm}$ \\
Length: $14 \mathrm{~mm}$ \\
Fill Gas: Argon+ \\
$4 \%$ \\
$\mathrm{~N}_{2}$ \\
Pressure : 5 bars
\end{tabular} & $\begin{array}{l}\text { Material: } \\
\text { SS347(impuritie } \\
\text { S of Co } 0.2 \% \text { ) } \\
\text { ID: } 2.5 \mathrm{~mm} \\
\text { OD: } 3 \mathrm{~mm} \\
\text { Length: } 33 \mathrm{~mm} \\
\text { except cable } \\
\text { Fill Gas: Argon+ } \\
4 \% \mathrm{~N}_{2}\end{array}$ & $\begin{array}{l}\text { Mineral cable } \\
\text { (1CCAc22Si50 } \\
\text { Ohms) } \\
\text { OD: } 2.2 \mathrm{~mm} \\
\text { Length: } 10 \mathrm{~mm} \\
\text { Materials } \\
\text { Sheath: SS304L } \\
\text { Insulation: SiO2 } \\
\text { (>99.5\%) } \\
\text { Wires: Copper } \\
\text { (impurities of } \\
\text { Zirconium } \\
\text { 0.19\%) } \\
\text { Shield: Copper }\end{array}$ & $\begin{array}{l}\text { Detector: } \\
\text { U-235: } 30 \mu \mathrm{g} \\
\mathrm{SS} 304:<2 \mathrm{~g} \\
\text { Fill Gas: }<5 \mathrm{E}-4 \mathrm{~g} \\
\text { Extension Cable: } \\
\mathrm{SS} 304:<300 \mathrm{~g} \\
\mathrm{SiO}_{2}:<12 \mathrm{~g} \\
\mathrm{Cu}:<8 \mathrm{~g}\end{array}$ \\
\hline $\begin{array}{l}\text { Miniature Fast } \\
\text { Fission } \\
\text { Chamber }\end{array}$ & $\begin{array}{l}\text { Mass: } 1000 \mu \mathrm{g} \\
\text { (deposit on cathode) } \\
\text { U-238 : } 99.964 \% \\
\text { U-235 : } 0.0354 \% \\
U-234: 0.0003 \%\end{array}$ & $\begin{array}{l}\text { Material: } \\
\text { SS316L } \\
\text { ID : / } \\
\text { OD: } 1 \mathrm{~mm} \\
\text { Length: } 51.5 \mathrm{~mm} \\
\text { Fill Gas: Argon } \\
\text { Pressure: } 9 \text { bars }\end{array}$ & $\begin{array}{l}\text { Material: } \\
\text { SS316L } \\
\text { ID: } 6.3 \mathrm{~mm} \\
\text { OD: } 8 \mathrm{~mm} \\
\text { Length: } 33.5 \\
\text { mm } \\
\text { Fill Gas: Argon } \\
\text { Pressure: } 9 \text { bars }\end{array}$ & $\begin{array}{l}\text { Organic cable } \\
\text { RG58BU } \\
\text { OD: } 6.15 \mathrm{~mm} \text {; } \\
\text { length } 10 \mathrm{~m} \\
\text { Materials } \\
\text { Sheath: PVC } \\
\text { Insulation: } \\
\text { polyethylene (PE) } \\
\text { Wires: copper clad } \\
\text { steel (CCS) }\end{array}$ & $\begin{array}{l}\text { Detector: } \\
\text { U-235: } 30 \mu \mathrm{g} \\
\text { SS316L }:<5 \mathrm{~g} \\
\text { Fill Gas: 1E-2 g } \\
\text { Extension Cable: } \\
\text { SS304: } 0 \mathrm{~g} \\
\text { PVC }:<30 \mathrm{~g} \\
\text { PE }:<15 \mathrm{~g} \\
\text { Wires: }<3 \mathrm{~g}\end{array}$ \\
\hline SPNDs & Emitter & Lead Wire(s) & Insulation & Sheath (Collector) & $\begin{array}{l}\text { Maximum Core } \\
\text { Insertion Mass }\end{array}$ \\
\hline $\begin{array}{l}\text { Hafnium } \\
\text { Manufacturer: } \\
\text { B\&W Fuel } \\
\text { Sensitivity } \\
4.7 \mathrm{e}-21 \mathrm{~A} / \mathrm{nv} \\
\text { (vendor } \\
\text { specified) }\end{array}$ & $\begin{array}{l}\text { Hafnium (minimum } \\
97.5 \% \text { with up to } 2.5 \% \\
\mathrm{Zr} \text { ) - fast response } \\
\text { Diameter: } 0.4572 \mathrm{~mm} \\
\text { Length: } \sim 400 \mathrm{~mm} \\
\text { (coiled to reduce } \\
\text { length) } \\
\text { Mass: } 0.873 \mathrm{~g} \\
\text { (nominal) }\end{array}$ & $\begin{array}{l}\text { Number: Two } \\
\text { Material: Inconel } \\
600 \\
\text { Diameter: } \\
0.203 \mathrm{~mm} \\
\end{array}$ & $\begin{array}{l}\mathrm{Al}_{2} \mathrm{O}_{3} \\
\text { Purity: 99.65\% } \\
\text { Compaction: } \\
\sim 70 \%\end{array}$ & $\begin{array}{l}\text { Inconel } 600 \\
\text { ID: } 0.904 \mathrm{~mm} \\
\text { OD: } 1.372 \mathrm{~mm}\end{array}$ & $\begin{array}{l}\text { Hafnium: } 0.897 \mathrm{~g} \\
\text { Inconel } 600: 9.02 \mathrm{~g} \\
\mathrm{Al}_{2} \mathrm{O}_{3}: 0.82 \mathrm{~g}\end{array}$ \\
\hline $\begin{array}{l}\text { Gadolinium } \\
\text { Manufacturer: } \\
\text { B\&W Fuel } \\
\text { Sensitivity } \\
\text { 5.0e-22A/nv } \\
\text { (vendor } \\
\text { specified) }\end{array}$ & $\begin{array}{l}\text { Gadolinium }(99.7 \%)- \\
\text { fast response } \\
\text { Diameter: } 0.559 \mathrm{~mm} \\
\text { Length: } \sim 25 \mathrm{~mm} \\
\text { Mass: } 0.0508 \mathrm{~g}\end{array}$ & $\begin{array}{l}\text { Number: Two } \\
\text { Material: Inconel } \\
600 \\
\text { Diameter: } \\
0.229 \mathrm{~mm}\end{array}$ & $\begin{array}{l}\mathrm{Al}_{2} \mathrm{O}_{3} \\
\text { Purity: } 99.65 \% \\
\text { Compaction: } \\
\sim 70 \% \\
\text { ID: } 0.559\end{array}$ & $\begin{array}{l}\text { Inconel } 600 \\
\text { ID: } 1.017 \mathrm{~mm} \\
\text { OD: } 1.575 \mathrm{~mm}\end{array}$ & $\begin{array}{l}\text { Gadolinium: } 0.055 \\
\mathrm{~g} \\
\text { Inconel } 600: 12.50 \\
\mathrm{~g} \\
\mathrm{Al}_{2} \mathrm{O}_{3}: 2.29 \mathrm{~g}\end{array}$ \\
\hline Rhodium & $\begin{array}{l}\text { Rhodium } \\
\text { Diameter - } 1 \mathrm{~mm} \\
\text { Length }-20 \mathrm{~mm}\end{array}$ & $\mathrm{Cu}$ & $\begin{array}{l}\text { Acrylic } \\
\text { ID: } 1.0 \mathrm{~mm} \\
\text { OD: } 1.5 \mathrm{~mm} \\
\text { Length: } 20 \mathrm{~mm}\end{array}$ & $\begin{array}{l}\text { SS-304 } \\
\text { ID: } 1.5 \mathrm{~mm} \\
\text { OD: } 1.9 \mathrm{~mm} \\
\text { Length: } 100 \mathrm{~mm}\end{array}$ & $\begin{array}{l}\text { Rhodium: 1g } \\
\text { SS:0.5 g }\end{array}$ \\
\hline Flux Wires & Materials & Diameter & $\begin{array}{l}\text { Maximum } \\
\text { Length }\end{array}$ & & $\begin{array}{l}\text { Maxium Core } \\
\text { Insertion mass }\end{array}$ \\
\hline & U235-Aluminum & $1 \mathrm{~mm}$ & $0.635 \mathrm{~cm}$ & & \\
\hline & Copper-1.55 Gold & $1 \mathrm{~mm}$ & $1.27 \mathrm{~cm}$ & & 10 grams \\
\hline
\end{tabular}


Table 3. In-core Neutron Detector Characteristics Under Evaluation

\begin{tabular}{|c|c|c|c|c|c|}
\hline Detector & \multicolumn{5}{|c|}{ Composition, Geometry, and Mass } \\
\hline Foils & Material & $\begin{array}{c}\text { Encapsulation } \\
\text { Material }\end{array}$ & $\begin{array}{l}\text { Maximum } \\
\text { Thickness } \\
(\mathrm{mm})\end{array}$ & Maximum Diameter & $\begin{array}{c}\text { Maximum Core } \\
\text { Insertion Mass }\end{array}$ \\
\hline \multirow{2}{*}{$\begin{array}{l}\text { Thermal-neutr } \\
\text { on Detection }\end{array}$} & Gold (100\%) & \multirow[t]{2}{*}{ None } & 0.0127 & $1 \mathrm{~cm}$ & $200 \mathrm{mg}$ \\
\hline & $\begin{array}{l}\text { Manganese-Copper } \\
(80 \% / 20 \%)\end{array}$ & & 0.0127 & $1 \mathrm{~cm}$ & $100 \mathrm{mg}$ \\
\hline \multirow{7}{*}{$\begin{array}{l}\text { Epithermal-neu } \\
\text { tron Detection }\end{array}$} & Indium $(>99 \%)$ & \multirow[t]{7}{*}{ Cadmium Covers } & \multirow[t]{7}{*}{0.0127} & \multirow[t]{7}{*}{$1 \mathrm{~cm}$} & \multirow[t]{5}{*}{$200 \mathrm{mg}$} \\
\hline & Gold (>99\%) & & & & \\
\hline & Tungsten $(>99 \%)$ & & & & \\
\hline & Cobalt $(>99 \%)$ & & & & \\
\hline & $\begin{array}{l}\text { Manganese-Copper } \\
(80 \% / 20 \%)\end{array}$ & & & & \\
\hline & Copper (>99\%) & & & & $400 \mathrm{mg}$ \\
\hline & Scandium (>99\%) & & & & $200 \mathrm{mg}$ \\
\hline \multirow{8}{*}{$\begin{array}{l}\text { Fast-neutron } \\
\text { Detection }\end{array}$} & Niobium $(>99 \%)$ & \multirow[t]{8}{*}{ Boron Sphere } & \multirow[t]{8}{*}{0.0127} & \multirow[t]{8}{*}{$2.54 \mathrm{~cm}$} & \multirow[t]{8}{*}{1 gram } \\
\hline & Rhodium (>99\%) & & & & \\
\hline & Indium $(>99 \%)$ & & & & \\
\hline & Titanium $(>99 \%)$ & & & & \\
\hline & Zinc $(>99 \%)$ & & & & \\
\hline & Nickel (>99\%) & & & & \\
\hline & Iron $(>99 \%)$ & & & & \\
\hline & Copper $(>99 \%)$ & & & & \\
\hline \multirow[t]{3}{*}{$\begin{array}{c}\text { Foil } \\
\text { Encapsulation }\end{array}$} & Material & Application & Thickness, mm & Diameter & Mass \\
\hline & Cadmium (> 99\%) & $\begin{array}{l}\text { Epithermal-neutron } \\
\text { Detection }\end{array}$ & 1 & $1.27 \mathrm{~cm}$ & $1 \mathrm{~g}$ \\
\hline & Boron Sphere $(>99 \%)$ & \begin{tabular}{|l} 
Fast-neutron \\
Detection
\end{tabular} & & $\begin{array}{l}2.54 \mathrm{~cm} \mathrm{OD} \\
1.27 \mathrm{~cm} \mathrm{ID}\end{array}$ & $115 \mathrm{~g}$ \\
\hline
\end{tabular}
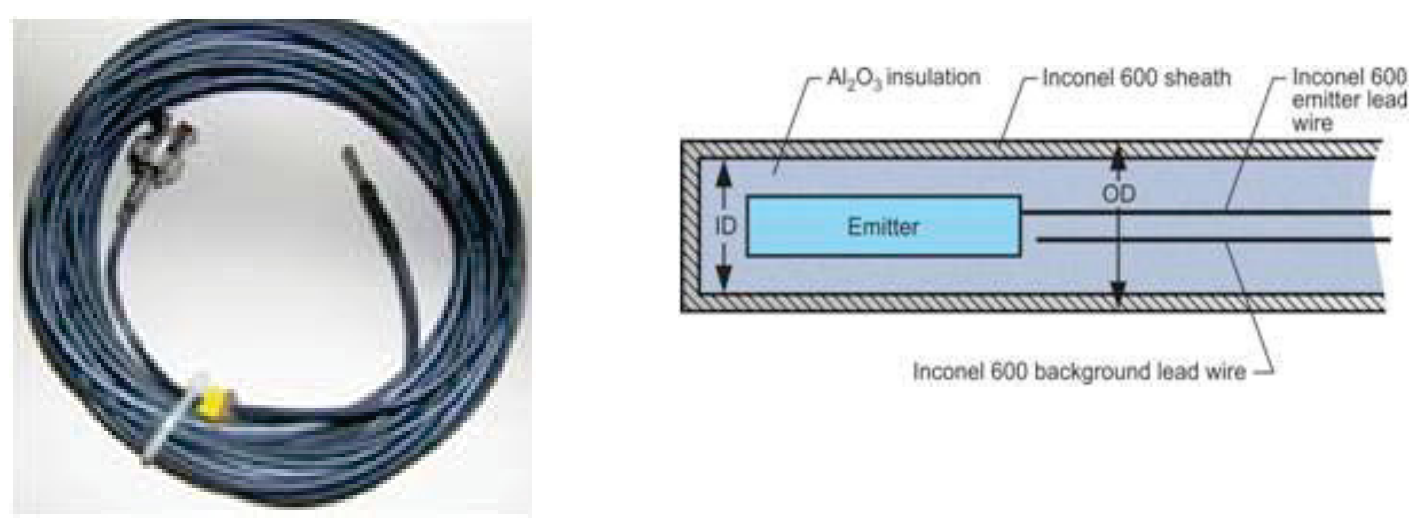

Figure 3. SPNDs 


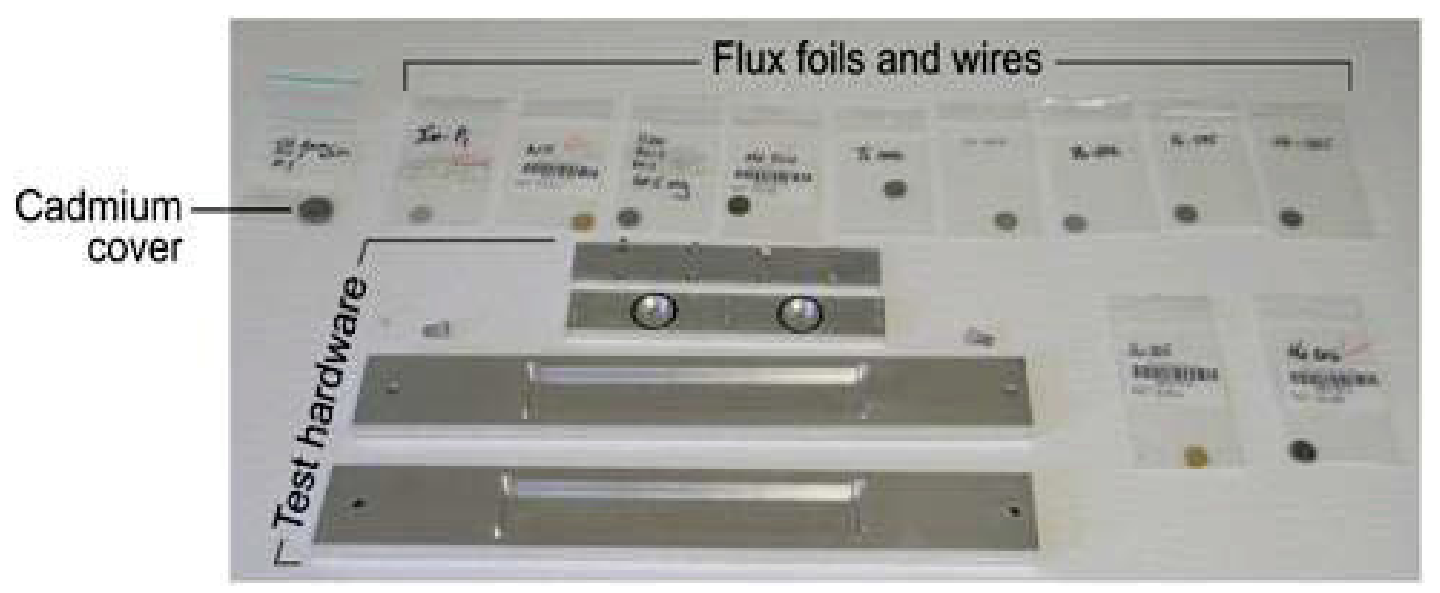

Figure 4. Flux Wires and Foils

A summary of the advantages and disadvantages of each type of in-core sensor is listed in Table 4.

Table 4. Standard In-core Neutron Detector Characteristics

\begin{tabular}{|c|c|c|}
\hline Option & Advantages & Disadvantages \\
\hline $\begin{array}{l}\text { Foils/ } \\
\text { Wires }\end{array}$ & $\begin{array}{ll}- & \text { Inexpensive } \\
- & \text { Small } \\
- & \text { Accurate }\end{array}$ & $\begin{array}{ll}\text { - } & \text { Only detect thermal or fast fluence } \\
\text { - } & \text { Requires post-irradiation analyses } \\
\text { - } & \text { Only real time } \\
& \text { Ontegral measurement }\end{array}$ \\
\hline SPNDs & $\begin{array}{ll}\text { - } & \text { Real time } \\
\text { - } & \text { No power supply needed } \\
\text { - } & \text { Small diameter } \\
\text { - } & \text { Good stability at high temperatures } \\
& \text { and pressures } \\
\text { - } & \text { Generate reproducible linear signal }\end{array}$ & $\begin{array}{ll}\text { - } & \text { Require calibration } \\
\text { - } & \text { Only detect thermal flux } \\
\text { Response time /lifetime/sensitivity tradeoff consider- } \\
\text { ations } \\
\text { - } \\
\text { Background discrimination required }\end{array}$ \\
\hline $\begin{array}{l}\text { Miniature } \\
\text { Fission } \\
\text { Chambers }\end{array}$ & $\begin{array}{l}\text { Real time } \\
\text { Thermal or fast neutron flux monitor- } \\
\text { ing, depending on deposited fissile } \\
\text { material } \\
\text { - } \\
\text { Small diameter } \\
\text { Reproducible linear signal }\end{array}$ & $\begin{array}{ll}\text { - } & \text { Only fast or thermal flux } \\
\text { - } & \text { Require calibration } \\
\text { - } & \text { High temperature survivability } \\
\text { - } & \text { High pressure fill gas } \\
\text { - } & \text { Lifetime /sensitivity/flux tradeoff considerations } \\
\text { - } & \text { Gamma discrimination required }\end{array}$ \\
\hline
\end{tabular}

\subsubsection{Experimental hardware}

In-core sensors were inserted into the ATRC in N-16 positions using Experiment Guide Tubes (EGTs). The EGTs are primarily fabricated from aluminum to minimize their weight. However, selected components, such as the guide tube shown in Figure 5 are made from stainless steel 304 for additional robustness. As illustrated in Figure 5, the six EGTs mechanically position detectors at a specified vertical location in the four N-16 exterior positions and two Center Flux Trap N-16 positions. The EGTs were supported above the reactor by attaching to the reactor control bridge. 
The position control and detector response are controlled and measured via LabView software to allow all sensors to either individually or simultaneously move and measure the local neutron flux and provide a three-dimensional measurement of the overall neutron flux.

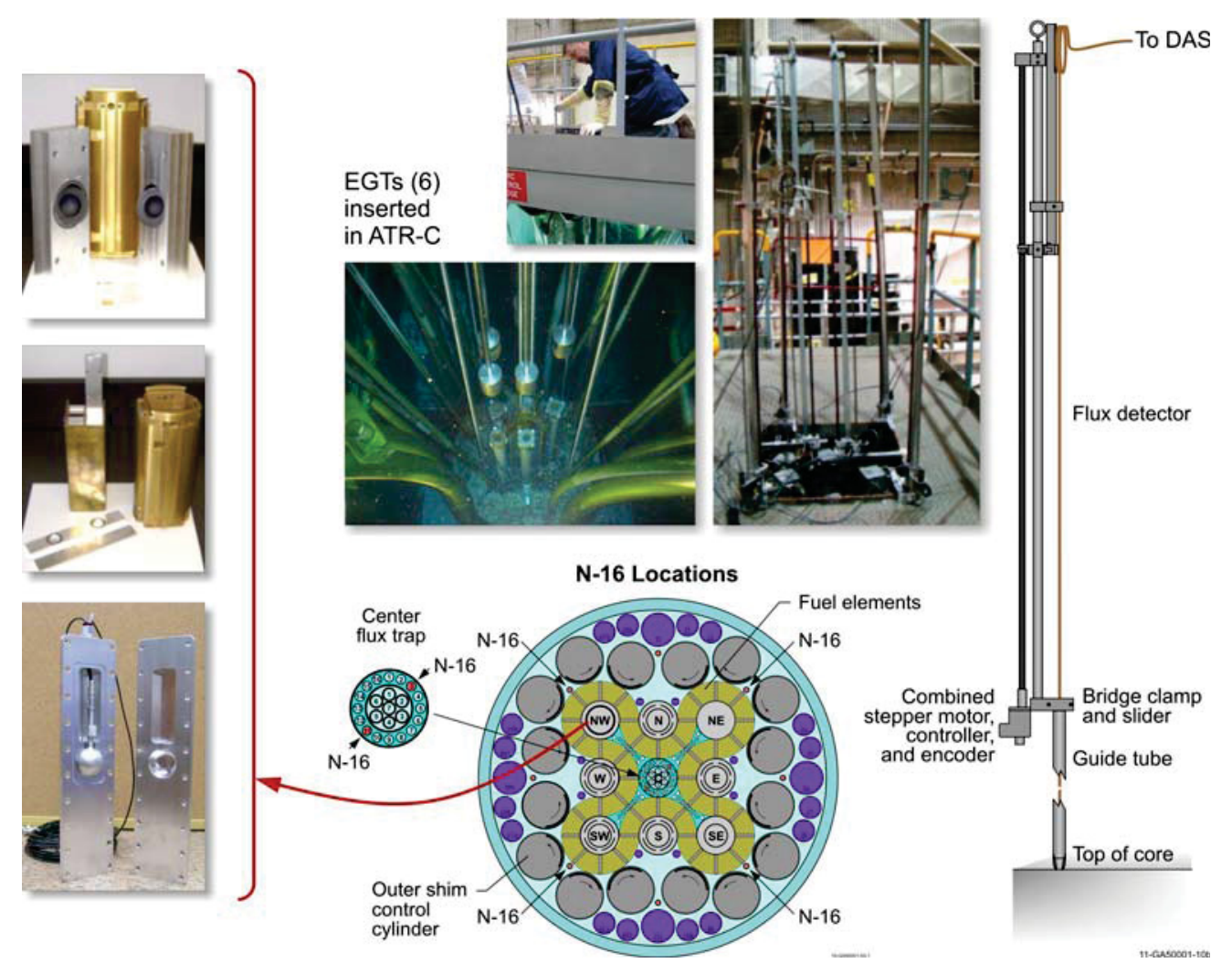

Figure 5. EGTs in ATRC 


\section{EXPERIMENTAL OBSERVATIONS}

Detector evaluations were performed for a variety of operational conditions. As previously discussed, the reactor was brought to specified power levels between $0.01 \mathrm{~W}$ and $600 \mathrm{~W}$. In addition, measurements were taken with the reactor shut down prior to startup and with the reactor shut down after startup. In order to assess if the detectors could be used to monitor various power splits, the reactor was purposely operated in an unbalanced condition, meaning the OSCCs in the NW lobe were positioned at +/-4 degrees from their nominal critical position. The following sections summarize the initial observations from experimental data collection and initial analysis.

\subsection{Testing}

As noted previously, the purpose of this project was to gain a more complete understanding of in-core sensor performance in a nuclear reactor. The response of various sensors were compared in numerous operational conditions to determine their usefulness for reactor operations and reactor experiments. Initially, the sensors were verified to be operational, then the detectors were used to track reactor power. Typical data obtained from power level testing in test 8 is shown in Figure 6.

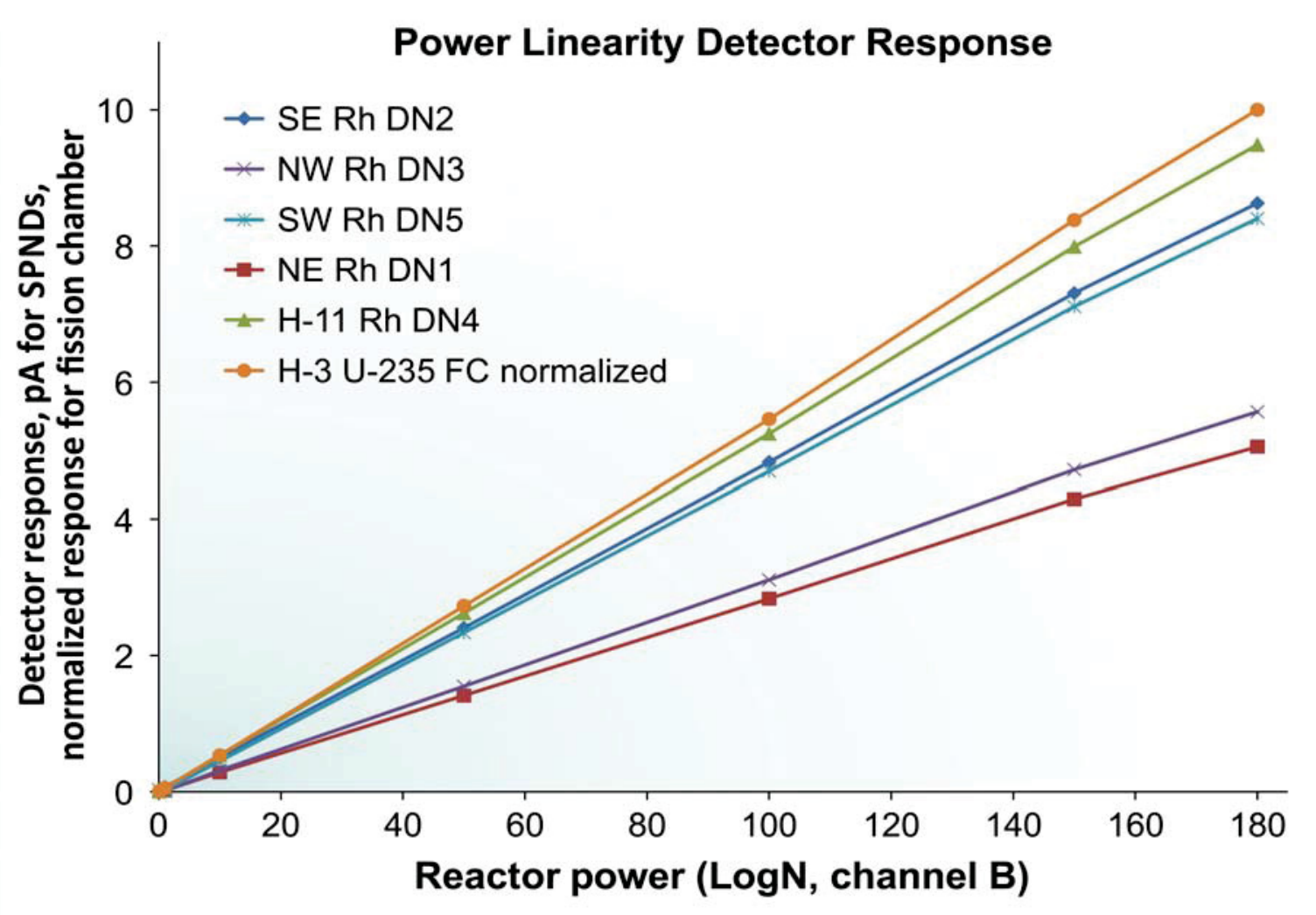

Figure 6. Comparison of Power Measurements Obtained from Rhodium SPNDs and a Fission Chamber from Activity III, Test 8, Experimental Configuration C 
Further testing continued by measuring the axial flux profile across the full length of travel of the EGTs. The position started outside the core above the reactor and contiued until the EGTs reached the lower limit touching the bottom reactor support plate. The transition between the active region of the core top and bottom of the core seems to be the most pronounced in the center flux trap positions, H-3 and H-11. Representative data obtained from axial flux testing from test 8 is shown in Figure 7.

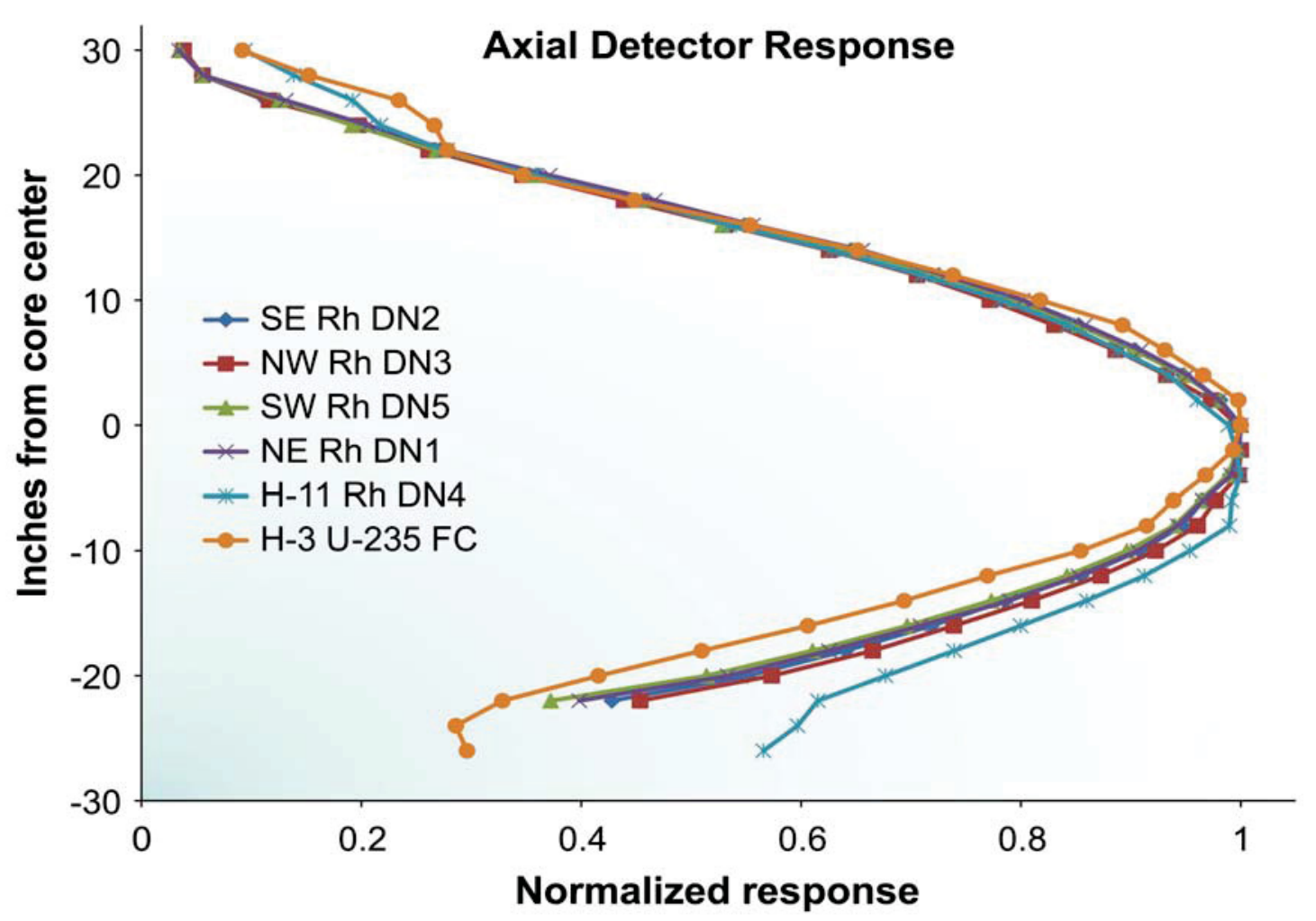

Figure 7. Axial Flux Profile from Rhodium SPNDs and a Fission Chamber from Activity III, Test 8, Experimental Configuration C

In addition to data collection, various insights were gained during the testing of the in-core sensors related to installation, operation, and data analysis and are summarized in the following sections.

\subsubsection{Signal Response}

Each type of detector demonstrated unique signal responses. The SPNDs displayed a current from -0.04 to 6 pico-amps. Due to the half-lives of the emitter materials, each type of SPND demonstrated a different response time for the signal to stabilize. Similarly, the decay of each type of emitter required careful consideration when monitoring power drops or recoveries from a reactor shutdown. This phenomenon can be seen on Figure 8 when the reactor was shut down during the middle of testing and the Hf-657, Hf- 658 , and Gd-663 signals did not return to the same values prior to shutdown. 


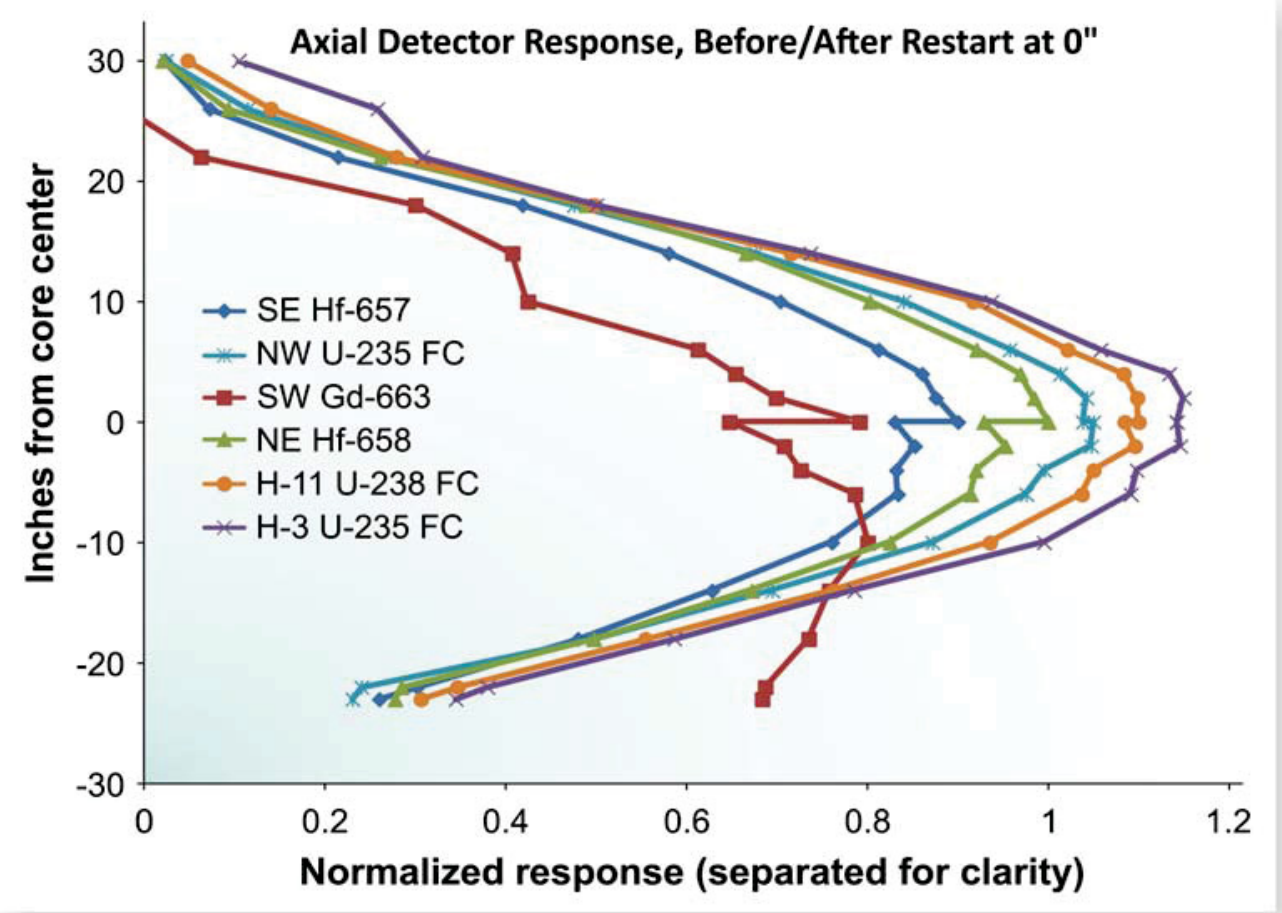

Figure 8. Axial Flux Profile from Rhodium SPNDs and a Fission Chamber, Before and After a Reactor Restart with the EGTs Located at Core Centerline from Activity III, Test 2, Experimental Configuration A

The fission chambers displayed electrical pulses that corresponded to count rates from 0 to $4 \times 10^{6}$ counts per second (cps). Unlike the response from the SPNDs, the response from the fission chambers did not have delays built into their signals. In addition, the fission chambers responded instantaneously to reactor power changes. As shown in Figure 8, the fission chamber signals returned to essentially the same value prior to a shutdown, whereas the SPND signals varied.

\subsubsection{Power Level Linearity}

The detector responses were checked at reactor instrument Log-N channel B readings of 0.00065 (shut down) $0.02,0.1,1,10,50,50,100,150$ and 180 (approximately $600 \mathrm{~W}$ ). As shown in Figure 6, all the detectors demonstrated a linear response to reactor power changes; but depending on core location, the slopes differed between the detectors in the north, south and center locations. This phenomenon was observed in all detectors. Hence, it is suspected that power in various core locations varies linearly with reactor power, but not equally with reactor power.

\subsubsection{Detector Failures}

One of the SPNDs and one of the fission chambers experienced failure during testing. Both failures were due to water egress in the dry tubes, eventually shorting the detectors that were not constructed to be leak-tight. The wet Rh SPNDs displayed a signal in the micro-amp range, which is several orders of magnitude higher than the upper value of its typical range (pico-amps). The fission chamber displayed random 
noise pulses. CEA has indicated that a thorough drying of the fission chamber and cabling would likely return the fission chamber to its previous operational condition. It is suspected the SPND would similarly benefit from a through drying. However, the detectors could not be thoroughly dried and retested in this series of experiments

\subsubsection{Measurement Repeatability}

As previously discussed in 3.1.1 and 3.1.2, the measurement repeatability was very consistent for the fission chambers during all testing conditions and irradiation history. Due to the inherent manner in which SPNDs operate, the consistency of the measurements was closely related to their irradiation exposure. SPND response at the beginning of testing was not consistent with their response at the end of testing due to the increasing activation of the emitter during irradiation and decay of the emitter if the reactor is shut down during testing. SPND signal buildup during irradiation must be considered.

\subsubsection{Sensitivity Comparisons}

Detailed flux measurements using foils and wires in the N-16 positions have not been taken, so absolute sensitivities can not be determined. However, sensitivity comparisons between detectors can be deter-

mined by estimating the flux in the N-16 positions and by using cross-comparisons for each detector position. 


\section{CONCLUSION}

Various real-time in-core flux sensors have been evaluated at the ATRC as part of a joint ISU/INL/ CEA project funded through the ATR NSUF. The sensors were evaluated a various reactor power levels and at different positions throughout the core. The sensors were used to measure reactor lobe power as well as axial flux. Both fast and thermal neutron flux measurements were taken for comparison. These evaluations complete the ISU/INL/CEA project. However the new capabilities developed from this project are available for future testing and evaluations of in-core sensors.

\subsection{Experimental Setup and Testing}

During sensor evaluations, it was noted that several areas of operation could be improved upon in future testing. Most notably is that the dry tubes remain dry throughout testing. The dry tubes were initially inserted into the ATRC canal in 2010, so it is unknown when the water leaked into the tube in the NW $\mathrm{N}-16$ position. The Labview program developed for this project should be updated to allow for all drives to be moved simultaneously and to log data when requested.

Interfacing detector response with the reactor log count rate detectors would also aid in evaluations to verify the neutron flux remains constant throughout testing.

\subsubsection{Tests Requiring Further Evaluation}

The schedule to complete testing in the ATRC did not allow for appropriate drying of the fission chamber, so water ingress into the dry tube prevented further testing with the U-238 fission chamber. Further comparisons between thermal and fast flux would aid in understanding detector response between each type of detector.

Flux wire and foil measurements in the N-16 positions would be beneficial for comparisons between the real-time sensors and integral measurements.

\subsection{Future Work}

It is expected that in-core sensor evaluations will continue in the ATRC. The size and flexibility of the ATRC reactor core allows for alternative and advanced in-core sensors to be tested in a variety of conditions. Planned tests for future ATRC tesing are identified in this section.

\subsubsection{Back-to-Back (BTB) Fission chamber}

BTB fission chambers, which are often called $2 \pi$ fission chambers because they are designed to count almost all fission fragments emitting from a thin deposit in a $2 \pi$ solid angle, provide the most accurate measure of fission reaction rates. For the ATRC evaluations, BTB chambers, developed in the Zero Power Physics Reactor (ZPPR) programs will be used. The BTB fission chambers are bisected hollow aluminum spheres, with stainless steel collector plates attached to the inside spherical surface of each half of the detector. Two stainless steel foils, coated with uranium, plutonium, or neptunium, were positioned such 
that the uncoated sides are in contact. These foils act as the center divider inside the BTB chamber volume, and are kept at the same electrical potential. Each spherical half has its own purge gas (P-10, a mixture of argon and methane) supply and exhaust lines and coaxial cable signal leads.

The counting gas continuously flows through these fission chambers. This allows a chamber to be built that can be easily opened and allow fissile material deposits to be changed. There are two uses for this capability: first, one can cross-calibrate an unknown fissile material deposit to a known fissile material deposit; and second, reaction rate ratios such as spectral indices, are very accurate because the measurements of BTB fissile material deposits are made at precisely the same time. The disadvantage of this type of chamber is that it is limited in the amount of miniaturization possible. It is necessary to register all of the energy deposited by the fission fragments in order to ensure a full spectrum; and at atmospheric pressure, this range is relatively long. This requires a certain volume in the counting gas, which translates into a minimum fission chamber radius.

Initially, these BTB fission chambers were used for calibration of other detectors at ISU. However, specialized fixtures have been fabricated (see Figure 9) to allow a BTB fission chamber to be inserted into the ATRC NW LIPT alongside a CEA fission chamber to compare their response in near-identical flux conditions. The layout of the test fixture used to insert these BTB fission chambers into the ATRC is shown in Figure 10. Not shown is an additional insert for three in-core sensors to assess the flux gradient across the LIPT that can be used in place of the BTB fission chambers.

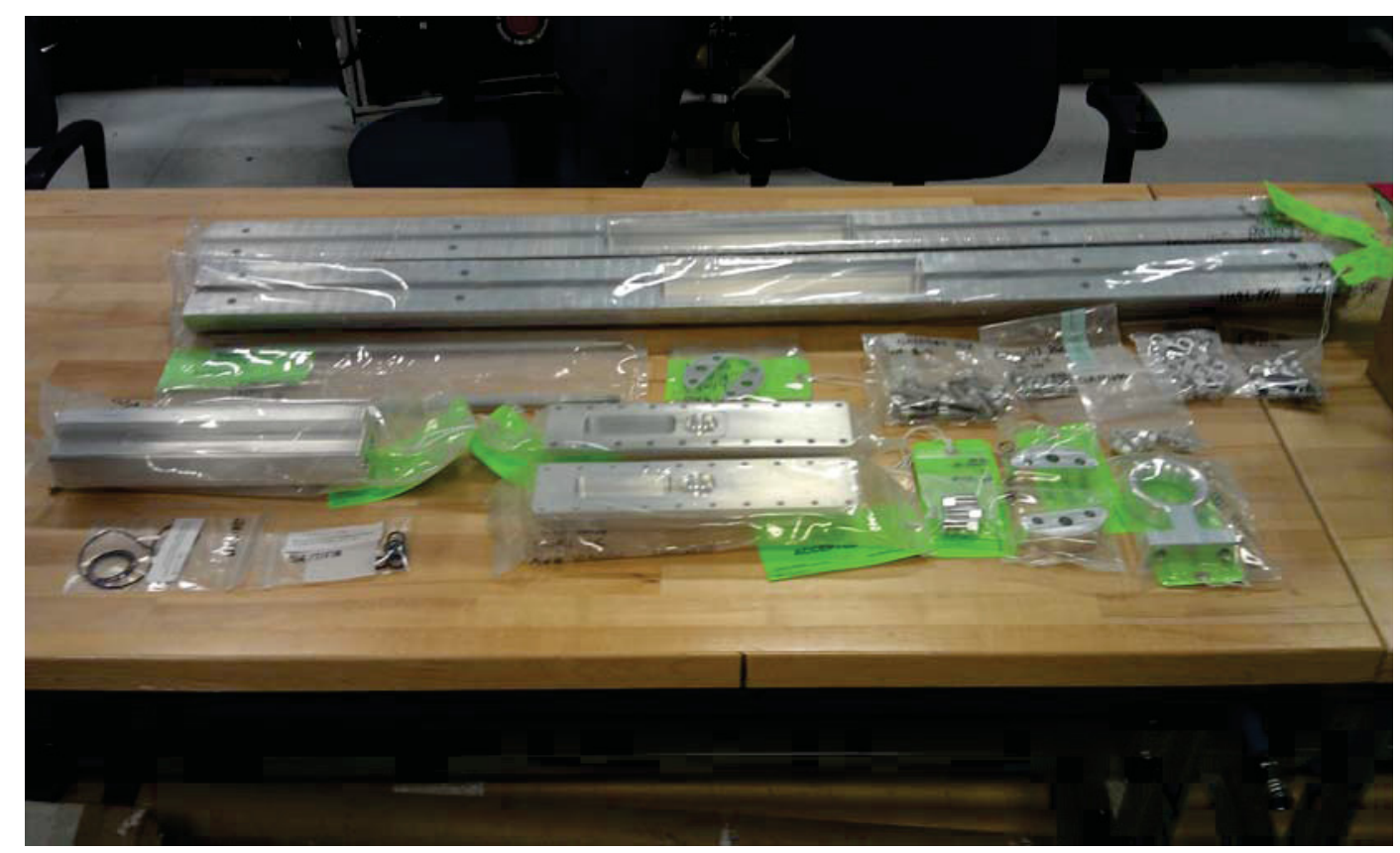

Figure 9. Fabricated Back-to-Back Fission Chamber Fixtures

The experimental hardware and procedures developed for this project will be available to other research programs needing to evaluate in-core sensors. Such sensors include Micro-Pocket Fission Detectors (MPFDs) for measuring thermal neutron flux, fast neutron flux and temperature simultaneously and Self-Powered Gamma Detectors (SPGDs) for measuring the gamma heating. 


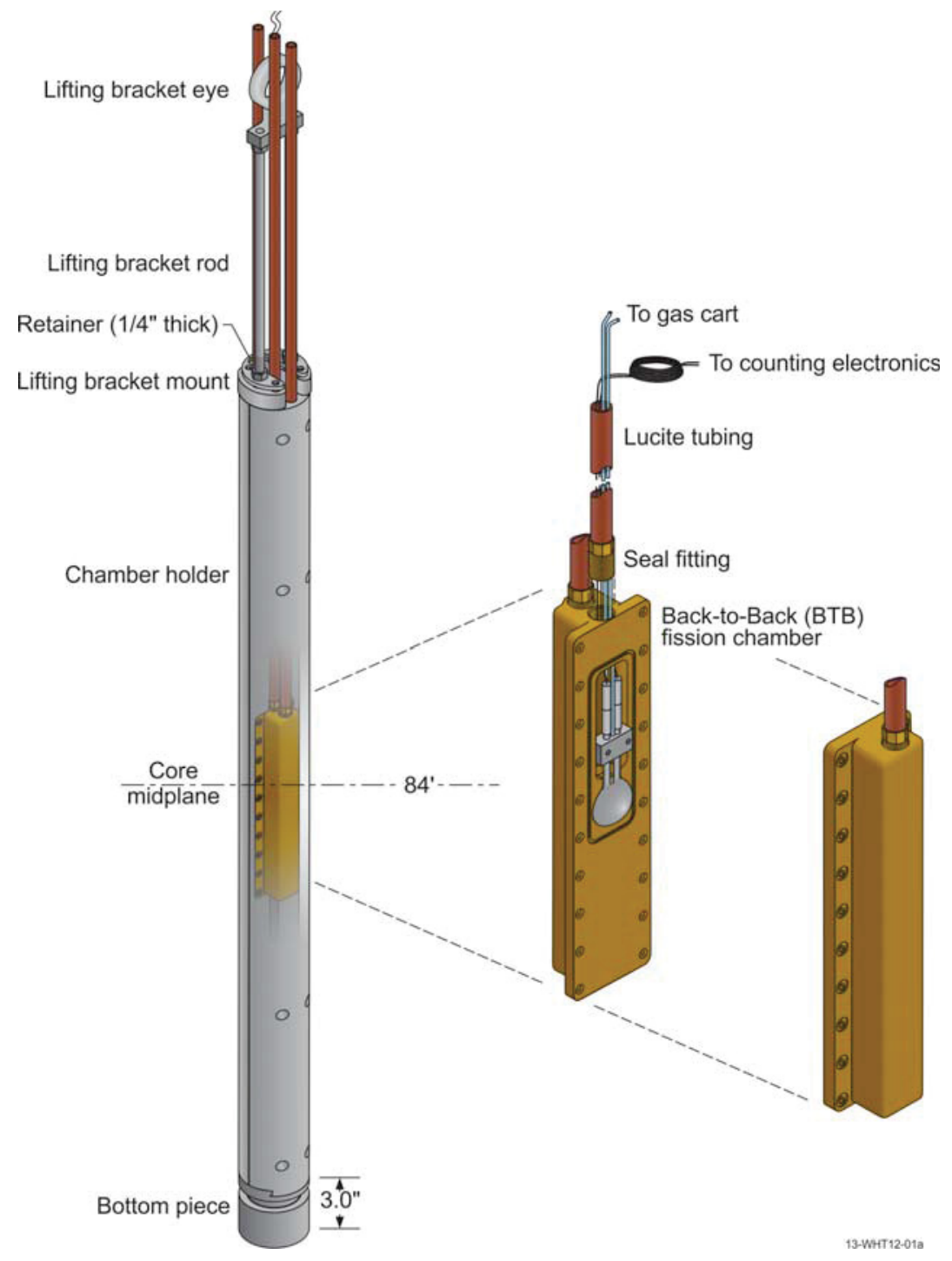

Figure 10. Back-to-Back Fission Chamber Hardware Assembly

\subsection{Recommendations}

The choice of a real-time in-core flux sensor depends on the end-use requirements. For the purpose of this project, the end-use requirements are based upon the desired experimental measurements in a materials and fuels test or operational information needed to aid in reactor operation.

\subsubsection{SPNDs}

The simplicity of SPNDs makes them well suited for a variety of measurement conditions. They are small, robust, do not require a power source and generate a steady current while in a thermal neutron field. However, the current response is delayed and requires careful consideration if used to monitor fast power transients. Materials and fuels test are generally only monitoring for anomalies in reactor flux, so the delay 
time associated with the use of SPNDs would be acceptable. However if the SPNDs are intended to be used as reactor power monitors, they will need to be supplemented with alternative fast response detectors for input into reactor safety systems. In addition, the SPNDs only operate at higher reactor powers, so they could not be used for the lower neutron fluxes encountered during a reactor startup.

\subsubsection{Fission Chambers}

The design of fission chambers is inherently more complicated than SPNDs; however, the fast response time associated with their operation can be a benefit for detection of neutron flux. The fission chambers also work well at low neutron fluxes, so it is expected they'd work well to monitor low level reactor power. In addition, very fast power transients would be more easily captured with fission chambers. Also, the fission chambers response does not seem to be heavily dependant on the previous irradiation history of the sensor. 


\section{REFERENCES}

1. J.L. Rempe and D.W. Nigg, FY-10 Irradiation Experiment Plan for the ATR National Scientific User Facility - Idaho State University Project Evaluating Flux, PLN-3351, April 2010

2. D.W. Nigg, J.L. Rempe, and T. Unruh, Qualification of Devices for Neutron Flux Measurements in the Advanced Test Reactor Critical Facility, TEV-885 Revision 1, July 2011.

3. Test Plan, TP-2-13, N-16 Experiment Guide Tube Testing, March 2011.

4. Test Plan, TP-2-10, “N-16 Experiment Guide Tube Mock-up fitment in ATRC, July 2010.

5. Test Plan, TP-4-10, N-16 Experiment Guide Tube Testing, October 2010.

6. Test Plan TP-3-10, Flux Runs for Activation Foil Measurements, November 2010.

7. Test Plan TP-4-13, Activation Foil Measurements - Irradiation 5, August 2013.

8. INL/EXT-10-19940, Advanced Test Reactor Core Modeling Update Project Annual Report for Fiscal Year 2010, September 2010.

9. INL/EXT-11-23348, Advanced Test Reactor Core Modeling Update Project Annual Report for Fiscal Year 2011, September 2011.

10. Test Plan, TP-4-12, SE-192 Reactivity and Axial Flux Measurement, November 2012.

11. ECAR-2089, RML Data Package Flux Run 12-8 TP-4-12, November 2011. 


\section{APPENDIX A.}

Table A-1. Activity III, Test 2, Experimental Configuration A, Axial Measurements

\begin{tabular}{|c|c|c|c|c|c|c|c|c|c|}
\hline & \multicolumn{9}{|c|}{ Detector Location and Name } \\
\hline & SE & SE & NW & SW & SW & NE & NE & H-11 & H-3 \\
\hline $\begin{array}{l}\text { Inches } \\
\text { from } \\
\text { core } \\
\text { center }\end{array}$ & $\begin{array}{c}\text { Hf-657 } \\
\text { primary } \\
\text { (pico-amps) }\end{array}$ & $\begin{array}{c}\text { Hf-657 } \\
\text { background } \\
\text { (pico-amps) }\end{array}$ & $\begin{array}{c}\text { U-235 FC } \\
2253 \\
\text { (counts per } \\
\text { minute) }\end{array}$ & $\begin{array}{c}\text { Gd-663 } \\
\text { primary } \\
\text { (pico-amps) }\end{array}$ & $\begin{array}{c}\text { Gd-663 } \\
\text { background }\end{array}$ & $\begin{array}{c}\text { Hf-658 } \\
\text { primary } \\
\text { (pico-amps) }\end{array}$ & $\begin{array}{c}\text { Hf-658 } \\
\text { background } \\
\text { (pico-amps) }\end{array}$ & $\begin{array}{c}\text { U-238 FC } \\
4 \\
\text { (counts per } \\
\text { minute) }\end{array}$ & $\begin{array}{c}\text { U-235 FC } \\
2252 \\
\text { (counts per } \\
\text { minute) }\end{array}$ \\
\hline 30 & 0.1439 & -0.0838 & 61036 & -0.0650 & -0.0867 & 0.0656 & -0.0566 & 5324 & 307259 \\
\hline 26 & 0.4675 & -0.1409 & 296890 & -0.0372 & -0.1561 & 0.3085 & -0.1638 & 15669 & 759577 \\
\hline 22 & 1.3934 & -0.1255 & 709507 & 0.1046 & -0.1272 & 0.8706 & -0.0717 & 31337 & 905151 \\
\hline 18 & 2.7240 & -0.0314 & 1240520 & 0.5058 & -0.0755 & 1.6316 & 0.0483 & 55931 & 1474480 \\
\hline 14 & 3.7801 & -0.0717 & 1765730 & 0.6872 & -0.0895 & 2.2225 & -0.0072 & 80438 & 2173540 \\
\hline 10 & 4.5847 & -0.1540 & 2193010 & 0.7163 & -0.1640 & 2.6802 & -0.1221 & 103128 & 2764740 \\
\hline 6 & 5.2939 & -0.0617 & 2499540 & 1.0343 & -0.0540 & 3.0755 & -0.0020 & 114894 & 3120740 \\
\hline 4 & 5.6075 & -0.0550 & 2646060 & 1.1048 & -0.0671 & 3.2370 & -0.0158 & 121877 & 3345020 \\
\hline 2 & 5.7068 & -0.0376 & 2721920 & 1.1803 & -0.0639 & 3.2882 & -0.0075 & 123574 & 3392620 \\
\hline 0 & 5.8672 & 0.0560 & 2711130 & 1.3370 & 0.0136 & 3.3405 & 0.1273 & 123752 & 3369610 \\
\hline 0 & 5.4104 & -0.1140 & 2741930 & 1.0932 & -0.0853 & 3.1014 & -0.0713 & 122004 & 3368210 \\
\hline-2 & 5.5564 & -0.0683 & 2735580 & 1.1957 & -0.0703 & 3.1821 & 0.0068 & 123283 & 3381450 \\
\hline-4 & 5.4225 & -0.0468 & 2599660 & 1.2264 & -0.0501 & 3.0726 & 0.0077 & 118119 & 3238690 \\
\hline-6 & 5.4334 & -0.0121 & 2547870 & 1.3284 & 0.0065 & 3.0542 & 0.0926 & 116666 & 3219760 \\
\hline-10 & 4.9580 & 0.0028 & 2277110 & 1.3518 & -0.0101 & 2.7555 & 0.0921 & 105234 & 2936000 \\
\hline-14 & 4.0922 & -0.0129 & 1813300 & 1.2801 & 0.0269 & 2.2431 & 0.1225 & 85751 & 2317110 \\
\hline-18 & 3.1248 & -0.0095 & 1294890 & 1.2417 & 0.0423 & 1.6605 & 0.1826 & 62314 & 1728690 \\
\hline-22 & 1.9649 & -0.0156 & 625701 & 1.1605 & 0.0687 & 0.9483 & 0.2081 & 38913 & 1118540 \\
\hline
\end{tabular}


Table A-2. Activity III, Test 2, Experimental Configuration A, Power Linearity Measurements

\begin{tabular}{|c|c|c|c|c|c|c|c|c|c|}
\cline { 2 - 10 } \multicolumn{1}{c|}{} & \multicolumn{9}{c|}{ Detector Location and Name } \\
\cline { 2 - 11 } & SE & SE & NW & SW & SW & NE & NE & H-11 & H-3 \\
\hline Power & $\begin{array}{c}\text { Hf-657 } \\
\text { primary }\end{array}$ & $\begin{array}{c}\text { Hf-657 } \\
\text { background }\end{array}$ & $\begin{array}{c}\text { U-235 FC } \\
\mathbf{2 2 5 3} \\
\text { (countsper } \\
\text { (pico-amps) }\end{array}$ & $\begin{array}{c}\text { Gd-663 } \\
\text { primary }\end{array}$ & $\begin{array}{c}\text { Gd-663 } \\
\text { background }\end{array}$ & $\begin{array}{c}\text { Hf-658 } \\
\text { primary } \\
\text { (pico-amps) }\end{array}$ & $\begin{array}{c}\text { Hf-658 } \\
\text { background }\end{array}$ & $\begin{array}{c}\text { U-238 FC } \\
\text { (pico-amps) } \\
\text { (counts per } \\
\text { minute) }\end{array}$ & $\begin{array}{c}\text { U-235 FC } \\
\mathbf{2 2 5 2} \\
\text { (counts per } \\
\text { minute) }\end{array}$ \\
\hline 180 & 5.8111 & 0.0774 & 2744220 & 1.3939 & 0.0330 & 3.3237 & 0.2016 & 123829 & 3375400 \\
\hline 150 & 4.5617 & -0.1510 & 2233710 & 0.8427 & -0.1415 & 2.5958 & -0.1291 & 102156 & 2793850 \\
\hline 100 & 3.0939 & -0.0477 & 1458210 & 0.6682 & -0.0687 & 1.7541 & 0.0000 & 66072 & 1816050 \\
\hline 50 & 1.6411 & 0.0020 & 748869 & 0.3819 & -0.0473 & 0.9098 & 0.0759 & 34264 & 935331 \\
\hline
\end{tabular}

Table A-3. Activity IV-A, Test 3, Experimental Configuration A, Power Split Measurements

\begin{tabular}{|c|c|c|c|c|c|c|c|c|c|}
\hline & \multicolumn{9}{|c|}{ Detector Location and Name } \\
\hline & SE & SE & NW & SW & SW & NE & NE & H-11 & H-3 \\
\hline $\begin{array}{c}\text { Estimated } \\
\text { Power and } \\
\text { Measured } \\
\text { Data }\end{array}$ & $\begin{array}{c}\text { Hf-657 } \\
\text { primary } \\
\text { (pico-amps) }\end{array}$ & $\begin{array}{c}\text { Hf-657 } \\
\text { background } \\
\text { (pico-amps) }\end{array}$ & $\begin{array}{c}\text { U-235 FC } \\
2253 \\
\text { (counts per } \\
\text { minute) }\end{array}$ & $\begin{array}{c}\text { Gd-663 } \\
\text { primary } \\
\text { (pico-amps) }\end{array}$ & 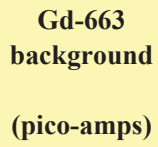 & $\begin{array}{c}\text { Hf-658 } \\
\text { primary } \\
\text { (pico-amps) }\end{array}$ & $\begin{array}{c}\text { Hf-658 } \\
\text { background }\end{array}$ & $\begin{array}{c}\text { U-238 FC } \\
4 \\
\text { (counts per } \\
\text { minute) }\end{array}$ & $\begin{array}{c}\text { U-235 FC } \\
2252 \\
\text { (counts per } \\
\text { minute) }\end{array}$ \\
\hline $\begin{array}{l}\text { Balanced } \\
\text { Estimated } \\
\text { Reactor } \\
\text { Power (W) }\end{array}$ & 57.27 & 57.27 & 39.75 & 56.71 & 56.71 & 40.53 & 40.53 & 55.74 & 55.74 \\
\hline $\begin{array}{c}\text { Balanced } \\
\text { Measured } \\
\text { Data }\end{array}$ & 5.5394 & -0.0578 & 2672660 & 1.1862 & -0.0571 & 3.1771 & 0.0049 & 117830 & 3432040 \\
\hline $\begin{array}{c}\text { NW OSCC } \\
+4 \text { Estimated } \\
\text { Reactor } \\
\text { Power (W) }\end{array}$ & 56.88 & 56.88 & 40.92 & 56.32 & 56.32 & 40.14 & 40.14 & 55.74 & 55.74 \\
\hline $\begin{array}{c}\text { NW OSCC } \\
+4 \text { Measured } \\
\text { Data }\end{array}$ & 5.4784 & -0.1058 & 2980200 & 1.0785 & -0.0877 & 3.1717 & -0.0308 & 121225 & 3429890 \\
\hline $\begin{array}{l}\text { NW OSCC } \\
-4 \text { Estimated } \\
\text { Reactor } \\
\text { Power (W) }\end{array}$ & 57.67 & 57.67 & 38.57 & 57.11 & 57.11 & 40.92 & 40.92 & 55.74 & 55.74 \\
\hline $\begin{array}{c}\text { NW OSCC } \\
-4 \text { Measured } \\
\text { Data }\end{array}$ & 5.7008 & -0.0575 & 2400040 & 1.1266 & -0.0879 & 3.2621 & -0.0231 & 119408 & 3401230 \\
\hline
\end{tabular}


Table A-4. Activity IV-A, Test 5, Experimental Configuration B, NW Balanced, Power Linearity Measurements

\begin{tabular}{|c|c|c|c|c|c|c|c|c|}
\hline & \multicolumn{8}{|c|}{ Detector Location and Name } \\
\hline & SE & SE & NW & SW & NE & H-11 & H-11 & H-3 \\
\hline $\begin{array}{l}\text { Power } \\
(\log N)\end{array}$ & $\begin{array}{c}\text { Hf-658 } \\
\text { primary } \\
\text { (pico-amps) }\end{array}$ & $\begin{array}{c}\text { Hf-658 } \\
\text { background }\end{array}$ & $\begin{array}{c}\text { U-238 FC } \\
4 \\
\text { (counts per } \\
\text { minute) }\end{array}$ & $\begin{array}{c}\text { U-235 FC } \\
2252 \\
\text { (counts per } \\
\text { minute) }\end{array}$ & $\begin{array}{c}\text { Rh DN1 } \\
\text { (pico-amps) }\end{array}$ & $\begin{array}{c}\text { Hf-657 } \\
\text { primary } \\
\text { (pico-amps) }\end{array}$ & $\begin{array}{c}\text { Hf-657 } \\
\text { background }\end{array}$ & $\begin{array}{c}\text { U-235 FC } \\
2253 \\
\text { (counts per } \\
\text { minute) }\end{array}$ \\
\hline 180 & 5.3917 & 0.0804 & 6800 & 4662350 & 5.0718 & 9.9886 & -0.1527 & 2969680 \\
\hline 150 & 4.3334 & 0.0155 & 41690 & 3719020 & 4.0605 & 8.1187 & -0.1745 & 2352610 \\
\hline 100 & 2.8983 & -0.1686 & 27923 & 2458530 & 2.5646 & 5.5013 & -0.2451 & 1535630 \\
\hline 50 & 1.5461 & -0.0272 & 14088 & 1200630 & 1.5076 & 3.1037 & -0.0352 & 751567 \\
\hline 10 & 0.3865 & -0.0639 & 2900 & 228574 & 0.2602 & 0.9007 & -0.1106 & 148415 \\
\hline
\end{tabular}

Table A-5. Activity IV-A, Test 5, Experimental Configuration B, NW Unbalanced +4, Power Linearity Measurements

\begin{tabular}{|c|c|c|c|c|c|c|c|c|}
\hline & \multicolumn{8}{|c|}{ Detector Location and Name } \\
\hline & SE & SE & NW & SW & NE & H-11 & H-11 & H-3 \\
\hline $\begin{array}{l}\text { Power } \\
(\log N)\end{array}$ & $\begin{array}{c}\text { Hf-658 } \\
\text { primary } \\
\text { (pico-amps) }\end{array}$ & $\begin{array}{c}\text { Hf-658 } \\
\text { background }\end{array}$ & $\begin{array}{c}\text { U-238 FC } \\
4 \\
\text { (counts per } \\
\text { minute) }\end{array}$ & $\begin{array}{c}\text { U-235 FC } \\
2252 \\
\text { (counts per } \\
\text { minute) }\end{array}$ & $\begin{array}{c}\text { Rh DN1 } \\
\text { (pico-amps) }\end{array}$ & $\begin{array}{c}\text { Hf-657 } \\
\text { primary } \\
\text { (pico-amps) }\end{array}$ & 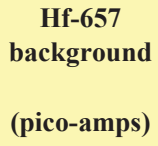 & $\begin{array}{c}\text { U-235 FC } \\
2253 \\
\text { (counts per } \\
\text { minute) }\end{array}$ \\
\hline 180 & 5.3493 & 0.0485 & -233920 & 4537990 & 4.9588 & 10.0502 & -0.1700 & 3022050 \\
\hline 150 & 4.5038 & 0.0054 & -266840 & 3754530 & 4.1994 & 8.5166 & -0.1261 & 2473880 \\
\hline 100 & 3.0500 & 0.0140 & -264100 & 2430180 & 2.8168 & 5.8436 & -0.1083 & 1609580 \\
\hline 50 & 1.5973 & -0.0392 & -259930 & 1201350 & 1.4253 & 3.1704 & -0.1206 & 797239 \\
\hline 10 & 0.4137 & -0.0535 & -268580 & 241091 & 0.3005 & 0.9609 & -0.0986 & 160326 \\
\hline
\end{tabular}


Table A-6. Activity IV-A, Test 5, Experimental Configuration B, NW Unbalanced -4, Power Linearity Measurements

\begin{tabular}{|c|c|c|c|c|c|c|c|c|}
\hline & \multicolumn{8}{|c|}{ Detector Location and Name } \\
\hline & SE & SE & NW & SW & NE & H-11 & H-11 & H-3 \\
\hline $\begin{array}{l}\text { Power } \\
(\log N)\end{array}$ & $\begin{array}{c}\text { Hf-658 } \\
\text { primary } \\
\text { (pico-amps) }\end{array}$ & $\begin{array}{c}\text { Hf-658 } \\
\text { background }\end{array}$ & $\begin{array}{c}\mathrm{U}-238 \mathrm{FC} \\
4 \\
\text { (counts per } \\
\text { minute) }\end{array}$ & $\begin{array}{c}\text { U-235 FC } \\
2252 \\
\text { (counts per } \\
\text { minute) }\end{array}$ & $\begin{array}{c}\text { Rh DN1 } \\
\text { (pico-amps) }\end{array}$ & $\begin{array}{c}\text { Hf-657 } \\
\text { primary } \\
\text { (pico-amps) }\end{array}$ & $\begin{array}{c}\text { Hf-657 } \\
\text { background }\end{array}$ & $\begin{array}{c}\text { U-235 FC } \\
2253 \\
\text { (counts per } \\
\text { minute) }\end{array}$ \\
\hline 180 & 5.4669 & 0.0963 & 5.0463 & 4593570 & 5.0986 & 9.8729 & -0.0983 & 2907890 \\
\hline 150 & 4.6068 & 0.0576 & 4.2485 & 3821780 & 4.2906 & 8.3431 & -0.0870 & 2412030 \\
\hline 100 & 3.1442 & 0.0458 & 2.8664 & 2504320 & 2.9468 & 5.7825 & -0.0685 & 1573830 \\
\hline 50 & 1.6300 & 0.0303 & 1.4437 & 1226200 & 1.4684 & 3.0390 & -0.0554 & 753877 \\
\hline 10 & 0.4417 & -0.0034 & 0.3212 & 245708 & 0.3323 & 0.9187 & -0.0233 & 149808 \\
\hline
\end{tabular}


Table A-7. Activity IV-A, Test 6, Experimental Configuration B, Balanced, Axial Measurements

\begin{tabular}{|c|c|c|c|c|c|c|c|c|}
\hline & \multicolumn{8}{|c|}{ Detector Location and Name } \\
\hline & SE & SE & NW & SW & NE & H-11 & H-11 & H-3 \\
\hline $\begin{array}{l}\text { Inches } \\
\text { from } \\
\text { core } \\
\text { center }\end{array}$ & $\begin{array}{c}\text { Hf-658 } \\
\text { primary } \\
\text { (pico-amps) }\end{array}$ & $\begin{array}{c}\text { Hf-658 } \\
\text { background }\end{array}$ & $\begin{array}{c}\text { U-238 FC } \\
4 \\
\text { (counts per } \\
\text { minute) }\end{array}$ & $\begin{array}{c}\text { U-235 FC } \\
2252 \\
\text { (counts per } \\
\text { minute) }\end{array}$ & $\begin{array}{c}\text { Rh DN1 } \\
\text { (pico-amps) }\end{array}$ & $\begin{array}{c}\text { Hf-657 } \\
\text { primary } \\
\text { (pico-amps) }\end{array}$ & $\begin{array}{c}\text { Hf-657 } \\
\text { background }\end{array}$ & $\begin{array}{c}\text { U-235 FC } \\
2253 \\
\text { (counts per } \\
\text { minute) }\end{array}$ \\
\hline 30 & 0.0502 & -0.1253 & $\mathrm{n} / \mathrm{a}$ & 79119 & -0.0737 & 0.4674 & -0.1155 & 261902 \\
\hline 26 & 0.4007 & -0.1089 & $\mathrm{n} / \mathrm{a}$ & 416183 & 0.4124 & 1.3035 & -0.1204 & 662979 \\
\hline 22 & 1.1866 & 0.0277 & $\mathrm{n} / \mathrm{a}$ & 1100450 & 1.0315 & 3.0560 & -0.1166 & 794495 \\
\hline 18 & 2.3926 & -0.0794 & 23928 & 1986050 & 2.1675 & 4.7900 & -0.1501 & 1325920 \\
\hline 14 & 3.4004 & -0.0828 & 33784 & 2963910 & 3.0504 & 6.7144 & -0.1418 & 1919390 \\
\hline 10 & 4.2996 & -0.0727 & 41398 & 3739290 & 3.8952 & 8.3271 & -0.1798 & 2439150 \\
\hline 6 & 4.9209 & -0.0386 & 50334 & 4292160 & 4.5058 & 9.3326 & -0.1880 & 2831800 \\
\hline 2 & 5.1846 & 0.0189 & 39845 & 4779800 & 4.8756 & 9.7293 & -0.2248 & 2927650 \\
\hline 0 & 5.2617 & -0.1283 & 25443 & 4671240 & 4.8101 & 9.7979 & -0.2626 & 2972630 \\
\hline-2 & 5.3409 & 0.0544 & 31812 & 4638660 & 5.0606 & 9.8613 & -0.2060 & 2969220 \\
\hline-6 & 5.0404 & 0.0784 & 11042 & 4315890 & 4.8607 & 9.2607 & -0.2409 & 2816770 \\
\hline-10 & 4.5349 & 0.0927 & 27857 & 3870250 & 4.5076 & 8.2408 & -0.2540 & 2548280 \\
\hline-14 & 3.7328 & -0.0392 & 23923 & 3157360 & 3.6840 & 6.6268 & -0.4186 & 2100960 \\
\hline-18 & 2.8470 & 0.1203 & 12971 & 2230930 & 3.1139 & 5.0081 & -0.2906 & 1541550 \\
\hline-22 & 1.7773 & 0.3242 & 8113 & 1011800 & 2.0594 & 3.2188 & -0.2075 & 980447 \\
\hline
\end{tabular}


Table A-8. Activity IV-A, Test 6, Experimental Configuration B, NW Unbalanced +4, Axial Measurements

\begin{tabular}{|c|c|c|c|c|c|c|c|c|}
\hline & \multicolumn{8}{|c|}{ Detector Location and Name } \\
\hline & SE & SE & NW & SW & NE & H-11 & H-11 & H-3 \\
\hline $\begin{array}{l}\text { Inches } \\
\text { from } \\
\text { core } \\
\text { center }\end{array}$ & $\begin{array}{c}\text { Hf-658 } \\
\text { primary } \\
\text { (pico-amps) }\end{array}$ & $\begin{array}{c}\text { Hf-658 } \\
\text { background }\end{array}$ & $\begin{array}{c}\text { U-238 FC } \\
4 \\
\text { (counts per } \\
\text { minute) }\end{array}$ & $\begin{array}{c}\text { U-235 FC } \\
2252 \\
\text { (counts per } \\
\text { minute) }\end{array}$ & $\begin{array}{c}\text { Rh DN1 } \\
\text { (pico-amps) }\end{array}$ & $\begin{array}{c}\text { Hf-657 } \\
\text { primary } \\
\text { (pico-amps) }\end{array}$ & $\begin{array}{c}\text { Hf-657 } \\
\text { background }\end{array}$ & $\begin{array}{c}\text { U-235 FC } \\
2253 \\
\text { (counts per } \\
\text { minute) }\end{array}$ \\
\hline 30 & 0.0930 & -0.8560 & -103710 & 84130 & 0.1253 & 0.5736 & -0.0811 & 271875 \\
\hline 26 & 0.4637 & -0.0794 & -123340 & 423905 & 0.5890 & 1.4289 & -0.1053 & 695511 \\
\hline 22 & 1.3691 & -0.0476 & -124970 & 1071680 & 1.3329 & 2.9628 & -0.1019 & 836007 \\
\hline 18 & 2.4173 & -0.0683 & -123750 & 1955130 & 2.2508 & 4.9243 & -0.0809 & 1339120 \\
\hline 14 & 3.4571 & -0.0735 & -129640 & 2859510 & 3.1908 & 6.8630 & -0.0895 & 1948470 \\
\hline 10 & 4.3473 & -0.0148 & -137930 & 3643680 & 4.0157 & 8.4983 & -0.1210 & 2499170 \\
\hline 6 & 4.8566 & -0.0128 & -149540 & 4130190 & 4.5007 & 9.3353 & -0.1457 & 2811420 \\
\hline 4 & 5.1231 & 0.0257 & -150200 & 4315720 & 4.7438 & 9.7564 & -0.1571 & 2907780 \\
\hline 2 & 5.2358 & 0.0235 & -155000 & 4464970 & 4.9288 & 9.9554 & -0.1599 & 2990260 \\
\hline 0 & 5.3284 & 0.0436 & -154230 & 4532040 & 4.9877 & 10.0654 & -0.1619 & 3026720 \\
\hline-2 & 5.2653 & 0.0403 & -178660 & 4497190 & 4.9574 & 9.9248 & -0.1763 & 2986360 \\
\hline-4 & 5.1956 & 0.0400 & -172150 & 4397720 & 4.9174 & 9.7109 & -0.1885 & 2934220 \\
\hline-6 & 5.0361 & 0.0748 & -176180 & 4169610 & 4.7958 & 9.3189 & -0.1859 & 2827200 \\
\hline-10 & 4.4592 & 0.1121 & -173600 & 3662580 & 4.3991 & 8.2005 & -0.1993 & 2558700 \\
\hline-14 & 3.6818 & 0.1217 & -179750 & 3001390 & 3.8205 & 6.6409 & -0.2137 & 2072320 \\
\hline-18 & 2.8468 & 0.1628 & -201690 & 2174990 & 3.0776 & 4.9722 & -0.2135 & 1545490 \\
\hline-22 & 1.7473 & 0.2081 & -216010 & 998501 & 1.9217 & 3.0750 & -0.2247 & 991161 \\
\hline
\end{tabular}


Table A-9. Activity IV-A, Test 6, Experimental Configuration B, NW Unbalanced -4, Axial Measurements

\begin{tabular}{|c|c|c|c|c|c|c|c|c|}
\hline & \multicolumn{8}{|c|}{ Detector Location and Name } \\
\hline & SE & SE & NW & SW & NE & H-11 & H-11 & H-3 \\
\hline $\begin{array}{l}\text { Inches } \\
\text { from } \\
\text { core } \\
\text { center }\end{array}$ & $\begin{array}{c}\text { Hf-658 } \\
\text { primary } \\
\text { (pico-amps) }\end{array}$ & $\begin{array}{c}\text { Hf-658 } \\
\text { background }\end{array}$ & $\begin{array}{c}\mathrm{U}-238 \mathrm{FC} \\
4 \\
\text { (counts per } \\
\text { minute) }\end{array}$ & $\begin{array}{c}\text { U-235 FC } \\
2252 \\
\text { (counts per } \\
\text { minute) }\end{array}$ & $\begin{array}{c}\text { Rh DN1 } \\
\text { (pico-amps) }\end{array}$ & $\begin{array}{c}\text { Hf-657 } \\
\text { primary } \\
\text { (pico-amps) }\end{array}$ & $\begin{array}{c}\text { Hf-657 } \\
\text { background }\end{array}$ & $\begin{array}{c}\text { U-235 FC } \\
2253 \\
\text { (counts per } \\
\text { minute) }\end{array}$ \\
\hline 30 & 0.1871 & 0.0094 & 0.0963 & 83477 & 0.2070 & 0.5907 & -0.0158 & 262585 \\
\hline 26 & 0.5474 & -0.0069 & 0.5329 & 430109 & 0.6839 & 1.4738 & -0.0244 & 666566 \\
\hline 22 & 1.4511 & -0.0094 & 1.2354 & 1076560 & 1.3660 & 2.9329 & -0.0162 & 790417 \\
\hline 18 & 2.5244 & -0.0062 & 2.1233 & 1972360 & 2.3458 & 4.8729 & -0.0247 & 1305990 \\
\hline 14 & 3.5515 & 0.0017 & 3.0359 & 2887130 & 3.2311 & 6.6938 & -0.0367 & 1865370 \\
\hline 10 & 4.3856 & 0.0170 & 3.8024 & 3628270 & 4.0111 & 8.1445 & -0.0603 & 2380850 \\
\hline 6 & 4.9579 & 0.0606 & 4.3874 & 4188060 & 4.5733 & 9.0988 & -0.0765 & 2707020 \\
\hline 4 & 5.1704 & 0.0564 & 4.6448 & 4333760 & 4.8126 & 9.4896 & -0.0790 & 2812360 \\
\hline 2 & 5.2986 & 0.0774 & 4.8226 & 4469390 & 4.9288 & 9.6188 & -0.0845 & 2868290 \\
\hline 0 & 5.3931 & 0.0788 & 4.9637 & 4551020 & 5.0237 & 9.7485 & -0.0960 & 2896990 \\
\hline-2 & 5.3566 & 0.0944 & 5.0054 & 4555010 & 4.9896 & 9.5949 & -0.1023 & 2878140 \\
\hline-4 & 5.2612 & 0.1089 & 4.9796 & 4410650 & 4.9577 & 9.3721 & -0.1153 & 2842410 \\
\hline-6 & 5.0218 & 0.1073 & 4.8339 & 4154710 & 4.7915 & 8.9170 & -0.1172 & 2706270 \\
\hline-10 & 4.5533 & 0.1239 & 4.5697 & 3731150 & 4.4818 & 7.9767 & -0.1396 & 2455380 \\
\hline-14 & 3.8256 & 0.1722 & 4.0357 & 3067080 & 3.8917 & 6.5426 & -0.1471 & 2018490 \\
\hline-18 & 2.9225 & 0.1988 & 3.3413 & 2200700 & 3.1167 & 4.8540 & -0.1548 & 1492890 \\
\hline-22 & 1.7846 & 0.2299 & 2.2841 & 1000550 & 1.9298 & 2.9738 & -0.1574 & 955264 \\
\hline
\end{tabular}


Table A-10. Activity III, Test 8, Experimental Configuration C, Axial Measurements

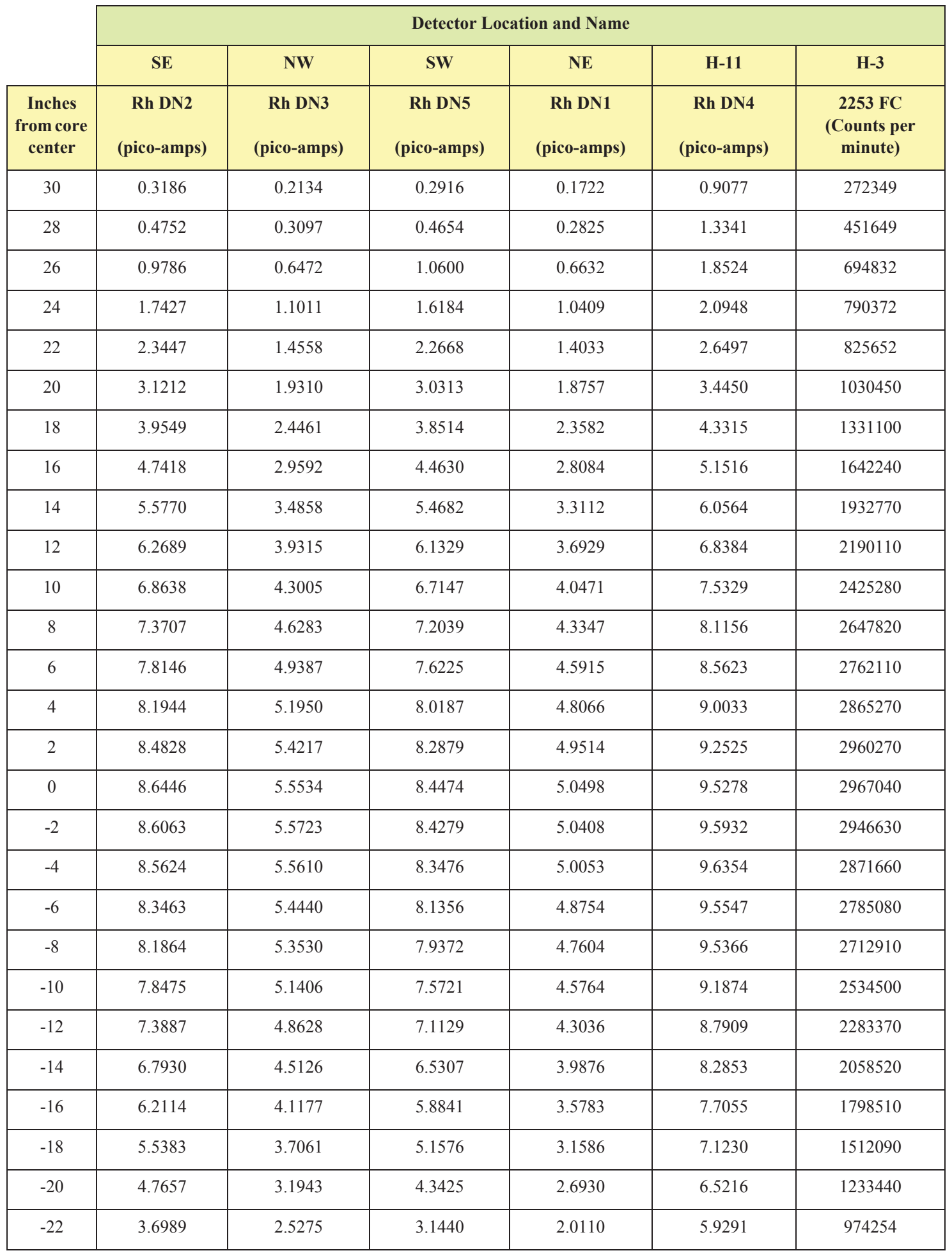


Table A-11. Activity III, Test 8, Experimental Configuration C, Power Linearity Measurements

\begin{tabular}{|c|c|c|c|c|c|c|}
\cline { 2 - 7 } & \multicolumn{7}{c|}{ SE } & NW & SW & NE & H-11 & H-3 \\
\cline { 2 - 7 } Power & Rh DN2 & Rh DN3 & Rh DN5 & Rh DN1 & Rh DN4 & $\begin{array}{c}\text { 2253 FC } \\
\text { (counts per } \\
\text { minute) }\end{array}$ \\
\hline 0.00065 & -0.6678 & -0.1353 & -0.1338 & -0.1404 & -0.0754 & 110 \\
\hline 0.02 & -0.0041 & -0.0282 & 0.0284 & -0.0327 & -0.0057 & 714 \\
\hline 0.1 & 0.0083 & -0.0185 & -0.0195 & -0.0007 & 0.0023 & 1848 \\
\hline 1 & 0.0667 & 0.0081 & 0.0227 & 0.0195 & 0.0550 & 15932 \\
\hline 10 & 0.5053 & 0.3122 & 0.4484 & 0.2836 & 0.5356 & 159262 \\
\hline 50 & 2.4053 & 1.5463 & 2.3343 & 1.4101 & 2.6198 & 814244 \\
\hline 100 & 4.8304 & 3.1085 & 4.6967 & 2.8329 & 5.2451 & 1629020 \\
\hline 150 & 7.3086 & 4.7185 & 7.1101 & 4.2915 & 7.9895 & 2500620 \\
\hline 180 & 8.6290 & 5.5662 & 8.4039 & 5.0546 & 9.4862 & 2983780 \\
\hline
\end{tabular}

Table A-12. Activity IV, Test 9, Experimental Configuration C, Power Split Measurements

\begin{tabular}{|c|c|c|c|c|c|c|}
\hline & \multicolumn{6}{|c|}{ Detector Location and Name } \\
\hline & SE & NW & SW & NE & H-11 & H-3 \\
\hline Estimated Power and Measured Data & $\begin{array}{c}\text { Rh DN2 } \\
\text { (pico-amps) }\end{array}$ & $\begin{array}{c}\text { Rh DN3 } \\
\text { (pico-amps) }\end{array}$ & $\begin{array}{c}\text { Rh DN5 } \\
\text { (pico-amps) }\end{array}$ & $\begin{array}{c}\text { Rh DN1 } \\
\text { (pico-amps) }\end{array}$ & $\begin{array}{c}\text { Rh DN4 } \\
\text { (pico-amps) }\end{array}$ & $\begin{array}{c}2253 \mathrm{FC} \\
\text { (counts per } \\
\text { minute) }\end{array}$ \\
\hline Balanced Estimated Reactor Power (W) & 57.27 & 39.75 & 56.71 & 40.53 & 55.74 & 55.74 \\
\hline Balanced Measured Data & 8.6290 & 5.5662 & 8.4039 & 5.0546 & 9.4862 & 2983780 \\
\hline NW OSCC +4 Estimated Reactor Power (W) & 56.88 & 40.92 & 56.32 & 40.14 & 55.74 & 55.74 \\
\hline NW OSCC +4 Measured Data & 5.5417 & 6.1237 & 8.3951 & 5.0518 & 9.6732 & 3043990 \\
\hline NW OSCC -4 Estimated Reactor Power (W) & 57.67 & 38.57 & 57.11 & 40.92 & 55.74 & 55.74 \\
\hline NW OSCC -4 Measured Data & 8.6169 & 4.9082 & 8.3217 & 5.0109 & 9.3182 & 2939940 \\
\hline
\end{tabular}


INL/EXT-13-29896 